\title{
Field Algae Measurements Using Empirical Correlations at Deer Creek Reservoir
}

Ryan A. Stephens

Brigham Young University - Provo

Follow this and additional works at: https://scholarsarchive.byu.edu/etd

Part of the Civil and Environmental Engineering Commons

\section{BYU ScholarsArchive Citation}

Stephens, Ryan A., "Field Algae Measurements Using Empirical Correlations at Deer Creek Reservoir" (2011). Theses and Dissertations. 2722.

https://scholarsarchive.byu.edu/etd/2722

This Thesis is brought to you for free and open access by BYU ScholarsArchive. It has been accepted for inclusion in Theses and Dissertations by an authorized administrator of BYU ScholarsArchive. For more information, please contact scholarsarchive@byu.edu, ellen_amatangelo@byu.edu. 
An Evaluation of Field Algae Measurements using Empirical

Correlations with an In Situ Probe at Deer Creek Reservoir

\author{
Ryan Stephens
}

A thesis submitted to the faculty of

Brigham Young University

in partial fulfillment of the requirements for the degree of

Master of Science

E. James Nelson, Chair

Gus P. Williams

Rollin H. Hotchkiss

Department of Civil and Environmental Engineering

Brigham Young University

June 2011

Copyright ( 2011 Ryan Stephens

All Rights Reserved 



\author{
ABSTRACT \\ An Evaluation of Field Algae Measurements using Empirical \\ Correlations with an In Situ Probe at Deer Creek Reservoir \\ Ryan Stephens \\ Department of Civil and Environmental Engineering \\ Master of Science
}

Deer Creek Reservoir in Utah has a history of high algae concentrations. Despite recent nutrient reduction efforts, seasonal algae continue to present problems. Cost effective, accurate, and comprehensive monitoring is important to understand the reservoir processes driving this problem and characterizing the algae spatial and temporal distributions are an important part of this effort. Current laboratory methods for accurately measuring algae are expensive and time consuming and are based on water samples taken in the field and transported to the laboratory. This approach only provides data for relatively few point samples because of the time and expense of sample collection and analysis. These relatively few samples do not describe the complex spatial and temporal trends in the algal data. Algae exhibit non-uniform distributions, especially in the vertical direction. In situ probes are able to measure chlorophyll-a and provide a less expensive measuring alternative than laboratory methods. These probes provide relatively quick, high resolution vertical profile measurements, which allows for more comprehensive horizontal and temporal sampling. To have confidence in the probe data, good correlations between in situ chlorophyll-a measurements and laboratory algae or chlorophyll measurements are important, but these correlations can be reservoir and time dependant as reservoir conditions change. Therefore, they must be developed for each study site.

This study reports on efforts at Deer Creek Reservoir to develop these correlations and provide a general description of the dynamic reservoir algal processes. I found that chlorophylla is weakly correlated to most algae species in the reservoir. However, it correlated well with total phytoplankton biovolume and the dominant algal species, which for this study was the diatom. Variations in correlation strength among the several algae species was assumed to most likely be affected by environmental factors, sample methods, algae species diversity, and the accuracy of the optical chlorophyll-a sensor. The data analysis indicate that the field methods used to obtain laboratory samples may have been a significant source of error because of the difficulty of matching the location of a probe measurement to the location of a sample. Field samples were not taken at the same depths as probe measurements and field samples from two locations were either mixed before laboratory analysis or the sample was a composite over a 2meter range. Based on my observations, I have made several recommendations to improve the accuracy of the correlation between algae and chlorophyll-a.

Keywords: Ryan Stephens, algae, chlorophyll, optical sensor, phytoplankton, Deer Creek 



\section{ACKNOWLEDGEMENTS}

I want to thank my advisor Dr. E. James Nelson, Dr. Gus P. Williams, and Dr. Rollin H. Hotchkiss for their input and support for this research. I would also like to thank Reed Obendorfer from the Central Utah Water Conservancy District who provided the field data for this study. I want to thank Oliver Obregon and the other members of the Brigham Young University Deer Creek research team for their support. Most importantly, I want to acknowledge my wife, Rachel and my son, Trevor. They have been my encouragement in helping me complete my research. 



\section{TABLE OF CONTENTS}

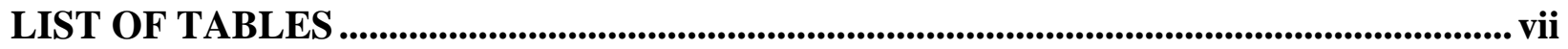

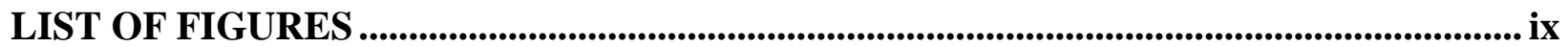

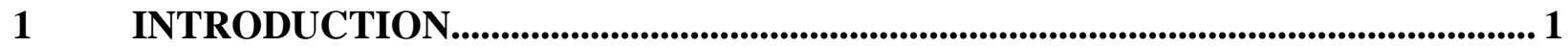

$1.1 \quad$ Background on Deer Creek Reservoir .................................................................. 1

1.2 Previous Studies on Algae and Chlorophyll Correlations........................................... 3

1.3 Problem Statement and Objectives ................................................................ 8

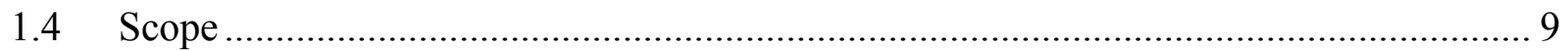

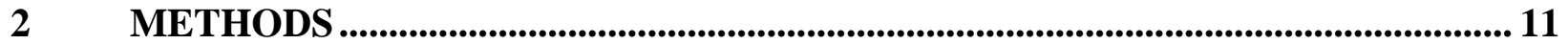

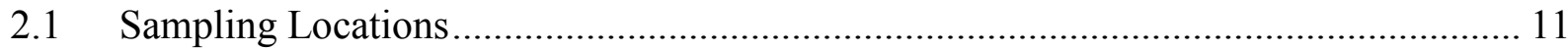

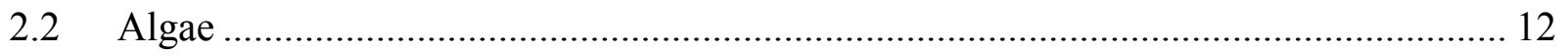

2.3 Chlorophyll-a and Algae Measurement Correlations............................................ 15

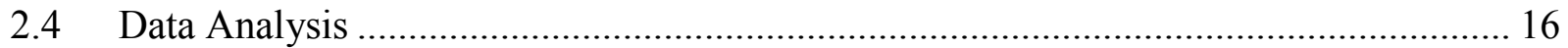

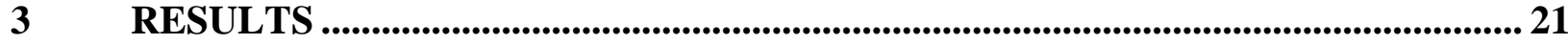

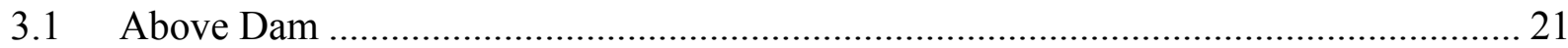

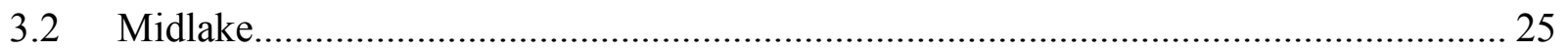

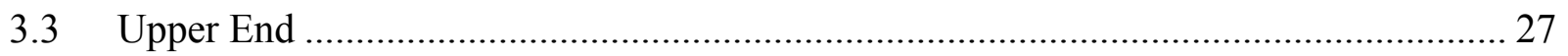

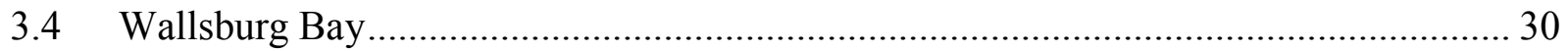

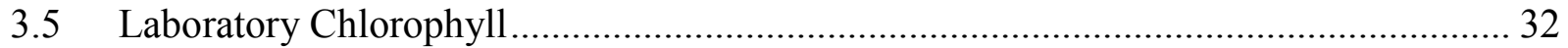




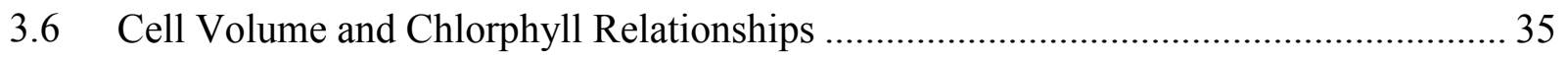

$4 \quad$ DISCUSSION AND CONCLUSIONS .............................................................................. 41

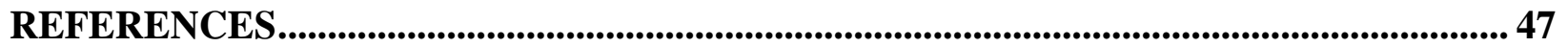




\section{LIST OF TABLES}

Table 3.1: Percentage of the amount of algae biovolume for each species found in the upper and lower euphotic zones and at the bottom.................................................... 22

Table 3.2: Percentage of the amount of algae biovolume for each species found in the upper and lower euphotic zones.............................................................................. 25

Table 3.3: Percentage of the amount of algae biovolume for each species found in the upper and lower euphotic zones.

Table 3.4: Percentage of the amount of algae biovolume for each species found in the upper and lower euphotic zones. 


\section{LIST OF FIGURES}

Figure 1.1: Deer Creek Reservoir 1

Figure 1.2: Deer Creek Reservoir Location (Google Earth Image) ....................................... 2

Figure 2.1: Sampling locations on Deer Creek Reservoir (Google Earth Image) ..................... 12

Figure 2.2: Figure showing the different sections of the euphotic zone ................................ 13

Figure 2.3: Image showing the location of the euphotic zone in a lake or reservoir (Association 2010)

Figure 2.4: A chlorophyll-a profile at the Above Dam site showing the locations water samples were taken. The boxes represent the locations of the algae samples. Mixing of the samples is shown by the lines connecting the boxes both the upper and lower euphotic zone.

Figure 2.5: Flow chart of sampling and data reduction for algae and chlorophyll-a 18

Figure 2.6: Flow chart for the statistical analysis done in this study 20

Figure 3.1: Regression results for total phytoplankton from the upper euphotic zone at the Above Dam site 23

Figure 3.2: Regression results for diatoms from the upper euphotic zone at the Above Dam site

Figure 3.3: Regression results for blue-green algae from the upper euphotic zone at the Above Dam site

Figure 3.4: Regression results for total phytoplankton in the upper euphotic zone at the Midlake site. 
Figure 3.5: Regression results for diatom biovolume in the upper euphotic zone at the Midlake site

Figure 3.6: Regression results for blue-green biovolume from the upper euphotic zone at the Midlake site.

Figure 3.7: Regression results for total phytoplankton in the upper euphotic zone at the Upper End site

Figure 3.8: Regression results for diatom biovolume from the upper euphotic zone at the Upper End site.

Figure 3.9: Regression results for cyanophyta biovolume for the upper euphotic zone at the Upper End site

Figure 3.10: Regression results for total phytoplankton in the upper euphotic zone at Wallsburg Bay 31

Figure 3.11: Regression results for diatom biovolume in the upper euphotic zone at the Wallsburg Bay site

Figure 3.12: Regression results for cyanophyta biovolume in the upper euphotic zone at Wallsburg Bay 32

Figure 3.13: Relationship between lab chlorophyll-a measurements and probe chlorophyll-a measurements ......

Figure 3.14: Correlation between lab chlorophyll-a measurements and diatom biovolume for the upper euphotic zone at the Above Dam, Midlake, and Upper End sites. 34

Figure 3.15: Correlation between probe chlorophyll-a measurements and diatom biovolume for the upper euphotic zone at the Above Dam, Midlake, and Upper End sites.

Figure 3.16: Chlorophyll-a mass to cell volume ratio relationship with total phytoplankton biovolume for the upper euphotic zone on Deer Cree Reservoir. 
Figure 3.17: Chlorophyll-a mass to cell volume ratio relationship with total phytoplankton biovolume for the lower euphotic zone on Deer Cree Reservoir

Figure 3.18: Chlorophyll-a concentration and phytoplankton biovolume time series at the Upper End site in the upper euphotic zone in 2009 and 2010

Figure 3.19: Chlorophyll-a concentration and phytoplankton biovolume time series at the Upper End site in the lower euphotic zone in 2009 and 2010

Figure 3.20: Monthly averages of several water quality parameters on Deer Creek Reservoir in 2010.

Figure 4.1: A chlorophyll-a profile at the Above Dam site showing the locations water samples were taken. The boxes represent the locations of the algae samples. Mixing of the samples is shown by the lines connecting the boxes both the upper and lower euphotic zone. 


\section{INTRODUCTION}

\subsection{Background on Deer Creek Reservoir}

Deer Creek Reservoir was constructed between 1938 and 1941 as part of the Provo River Project (David Eckhoff, Alane Boyd et al. 2002; Bell 2009). It is located in Wasatch County, Utah on the Provo River and provides drinking and irrigation water as well as recreation to residents of Utah, Wasatch, Summit, and Salt Lake Counties. The watershed drainage area for Deer Creek is 268.223 square miles, not including the drainage area for Jordanelle Reservoir (David Eckhoff, Alane Boyd et al. 2002). The reservoir's capacity is 152,700 acre-feet (Bell 2009). Figure 1.1 shows a photograph taken from middle of the reservoir looking south towards the dam while Figure 1.2 shows a map of the Deer Creek Reservoir location.

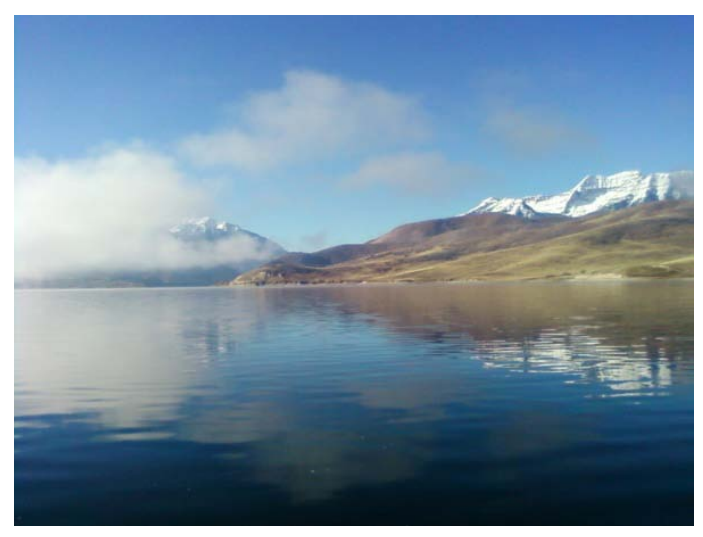

Figure 1.1: Deer Creek Reservoir 


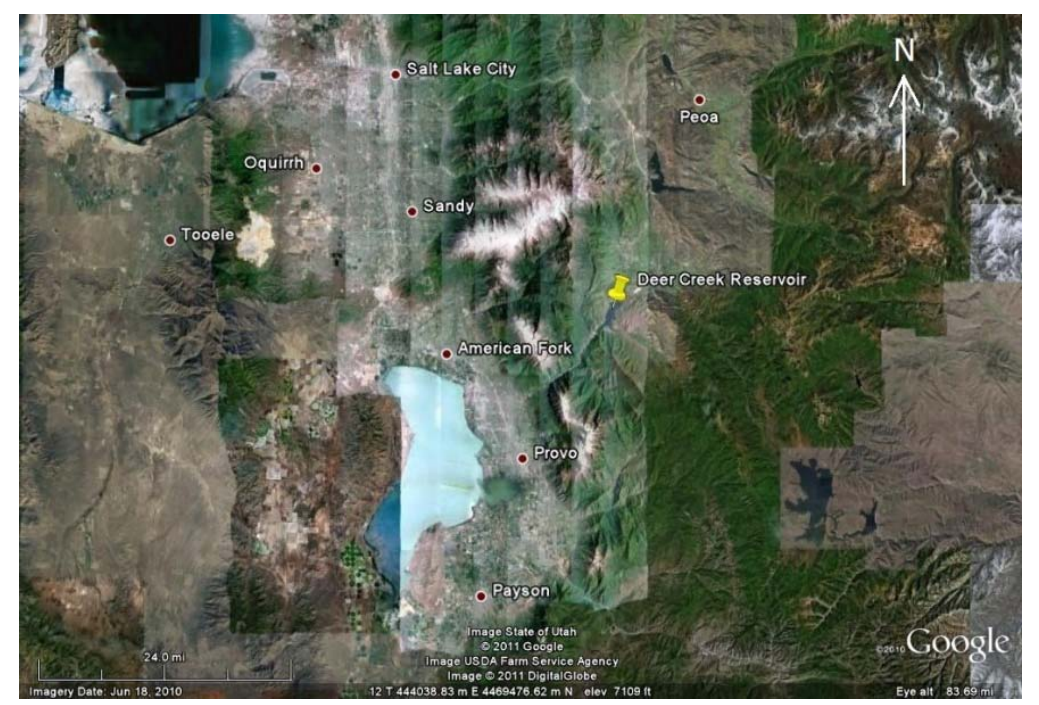

Figure 1.2: Deer Creek Reservoir Location (Google Earth Image)

In 1974 Deer Creek Reservoir was classified as eutrophic based on the Carlson's Trophic State Index (David Eckhoff, Alane Boyd et al. 2002). This classification was given because of high total phosphorus loadings and anaerobic conditions defined by low dissolved oxygen levels. In 1984 Utah Governor Scott Matheson issued the 1984 Water Quality Management Plan in an effort to improve the water quality of Deer Creek. The purpose of this plan was to control the total phosphorus loadings into the reservoir. In order to accomplish these goals, several projects and controls were implemented including the construction of Jordanelle Reservoir, the Provo River Restoration Project, controls set on nearby wastewater treatment plants, agricultural practices, animal feeding practices, and nearby fish hatcheries.

The effect of these controls on the nutrient loadings in the reservoir was evaluated and reported in the 2002 Total Maximum Daily Load (TMDL) study (David Eckhoff, Alane Boyd et al. 2002). The study showed that after the nutrient controls were implemented, the nutrient concentrations in the reservoir decreased. However, seasonal algae blooms continued to occur. 
The TMDL study set annual goals for algal biomass measurements as $5.1 \mu \mathrm{g} / \mathrm{L}$ chlorophyll-a, $6.5 \times 10^{7} \mathrm{um}^{3} / \mathrm{ml}$ biomass and $3.3 \times 10^{7} \mathrm{um}^{3} / \mathrm{ml}$ cyanophyta. Although the nutrient levels decreased, seasonal algae blooms continue to occur and exceed these limits.

In 2001, algae blooms caused serious taste and odor problems in the drinking water for the nearby Orem and Salt Lake City, Utah areas. The Orem Water Treatment Plant used activated carbon to remove the taste and odor from the water (David Eckhoff, Alane Boyd et al. 2002). As the reservoir supplies drinking water to a large population in northern Utah, the controls on nutrient loading into Deer Creek Reservoir were put into place to improve the water. These controls also acknowledge recreation as a primary use.

\subsection{Previous Studies on Algae and Chlorophyll Correlations}

To evaluate the controls placed on nutrient loadings, having an accurate method to estimate temporal and spatial algae measurements at high resolutions is important in order to understand the processes that drive algal growth. High resolution data, supported by continuing laboratory measurements, will help understand the reservoir processes, monitor and analyze implementation of the TMDL nutrient constraints, and to detect another incident. There are a number of measurement techniques that could be used. Studies have been done to find correlations between algae biomass and other water quality parameters such as phosphorus, secchi disc transparency, and chlorophyll-a concentration.

Nicholls and Dillon (1978) performed an evaluation of phosphorus-chlorophyllphytoplankton relationships for several lakes around the world. They compared more than 16 equations reported in the literature that defined relationships between chlorophyll-a and total phosphorus. All of these equations showed large differences in how chlorophyll-a related to 
phosphorus. They emphasized, however, that while there were large uncertainties in estimating phosphorus, chlorophyll-a concentration was widely used as an indicator for phytoplankton (Nicholls and Dillon 1978).

Their evaluation showed that the differences in the equations generally resulted from sampling methods, analytical methods, and fundamental morphometric and chemical characteristics of the lakes (Nicholls and Dillon 1978). Other factors in the variability of the estimates included the type of phosphate or chlorophyll measured such as total phosphorus or orthophosphate and whether the chlorophyll measurements were corrected for chlorophyll-b and c or if the chlorophyll measurements included all of the chlorophyll fractions.

Nicholls and Dillon (1978) noted that other problems may have been caused by the chlorophyll-a extraction procedure performed for the analysis. They also stated that total phosphorus "may not properly represent nutrients available for algal growth, nor may chlorophyll-a properly represent algal biomass" (Nicholls and Dillon 1978). They further stated that phytoplankton biomass, if recorded as chlorophyll-a, will be overestimated during development of a new community and underestimated during a community's decline. This emphasizes the fact that because chlorophyll-a concentration is affected by environmental factors, measurement techniques, and human errors, it may not be a consistent and accurate measure of algal biomass.

Nicholls and Dillon (1978) said that direct microscopic determination of algal biomass, such as cell counts, appeared to give the best estimate for phytoplankton biomass. However, they admit that the laboratory tests are tedious and costly.

Work to find relationships between chlorophyll-a, biomass, and nutrients has also been done on lakes in Florida. A study in Florida was done on 165 different lakes. Daniel E. Canfield 
et al. (1985) followed the advice of Nicholls and Dillon (1978) to use average cell volume or cell counts of phytoplankton samples to compare to chlorophyll-a concentrations. They found that there was "a significant positive correlation between chlorophyll-a concentrations and phytoplankton biomass" and the data showed an R value of 0.80 with large confidence limits for the relationship between the two variables (Canfield Jr, Linda et al. 1985). They investigated and reported relationships among chlorophyll-a, algal biomass, biovolume, total nitrogen, total phosphorus, and secchi disc transparencies.

Canfield et al. (1985) concluded that empirical phytoplankton relationships are not necessarily better defined if algal biomass data are used rather than chlorophyll-a concentrations. They suggest that chlorophyll-a measurements could be used to estimate algal biomass when limnological conditions, such as secchi disc transparency, suspended solids, or dissolved oxygen, range over orders of magnitude. They also found errors related to the direct microscopic determination of algal biomass. Due to the errors, cost, and tediousness of the microscopic procedure, they recommended chlorophyll-a measurements for estimating phytoplankton, despite variability in the chlorophyll-a per unit biomass ratio.

Other research on chlorophyll-a to biomass relationships has been done by Blanka Desortova (1981). They used spectrophotometric methods to measure chlorophyll-a concentrations and microscopic counting as well as measuring algal cell size to estimate phytoplankton biomass (Desortová 1981). Their analysis showed a strong correlation between chlorophyll-a concentration and algal biomass, annual mean chlorophyll-a concentration and algal biomass, percent chlorophyll-a in biomass and biomass, chlorophyll-a and flagellate biomass, and chlorophyll-a and blue-green algae biomass. Strong correlations were also found between chlorophyll-a and secchi disc transparency as well as chlorophyll-a and total 
phosphorus. As part of their study, they also evaluated a number of linear regression equations relating chlorophyll-a to algal biomass from the literature (Desortová 1981).

The literature presents several relationships involving nutrients, chlorophyll-a, secchi disc transparency, and algal biomass to estimate the amount of algae in lakes and reservoirs around the world. Several of the equations were developed by using regression analysis between chlorophyll-a and total phosphorus, total nitrate, or secchi disc transparency. The chlorophyll-a measurements are used in many of these studies because they are relatively easy to make and represent algae well enough to support reservoir management decisions, as demonstrated by the work quantifying correlations between chlorophyll-a and algal biomass (Vörös and Padisák 1991). These studies all note that because of variability in chlorophyll-a growth, algal growth, sampling methods, environmental impacts, equipment, and analytical methods, errors arise in the correlations.

The relationships between chlorophyll-a and algal biomass, shown by Desortova et al (1981) are strong but their paper does not acknowledge some other issues involved with laboratory determination of algae mass in the reservoir. The procedures used in all the reviewed studies for measuring chlorophyll-a and biomass including spectrophotometry and microscopic determination are costly. They are also based on a relatively small number of water samples which are taken to a laboratory to be analyzed. Unless enough samples were taken to define each water profile, the results are inconclusive as to biomass content between measured points in the water profile and across the reservoir. So while the laboratory measurements accurately determine the biomass present in the sample, the samples may not accurately its spatial distribution in the water body. 
As noted by the literature studies, chlorophyll-a is a key indicator of the presence of algae and is used to estimate algae biomass in many studies. Several methods are currently in use to measure chlorophyll-a concentration including laboratory extractions, in situ flouremetry, algal cell counting, high performance liquid chromatography, and other optical methods. These chlorophyll-a measurements are typically used as an indication of how much algae is present in the water, since actual chlorophyll concentrations are not the primary issue.

In Deer Creek Reservoir we have documented large vertical, horizontal, and temporal variability in algae distributions that cannot be resolved or well understood by traditional water samples. This shows that algae in reservoirs demonstrate complex spatial and temporal distributions. Using a small number of samples to define a reservoir's algae distribution may lead to errors or high uncertainties. An efficient high-resolution measurement method to measure either chlorophyll-a or algae biomass is needed to better understand the spatial and temporal distribution of algae in reservoirs. Deer Creek Reservoir has an aggressive monitoring plan, with samples taken monthly at four spatial locations using 6 to 8 vertical water samples per location plus a 2-meter composition sample taken for chlorophyll content. Even with this aggressive sampling, probe measurements show that the samples do not characterize the vertical algae distributions present in the water column very well. A better understanding of algae distribution will allow for better understanding of reservoir processes and support management decisions to reduce the occurrence of algae blooms. This type of high-resolution sampling requires a less expensive and less time consuming method to measure chlorophyll-a and algae biomass. This report explores the use of optical probes or sondes that measure algae on site using optical fluorescence methods. This report studies the correlation between probe-measured chlorophyll and two separate laboratory measurements; chlorophyll-a and algae biomass. 


\subsection{Problem Statement and Objectives}

This study reports on my efforts to develop empirical correlations between chlorophyll-a concentrations measured using an in situ optical sensor and algae biovolume measured in water samples from Deer Creek Reservoir using traditional laboratory methods. In this study, I also evaluate empirical correlations between the probe and laboratory measured chlorophyll concentrations

The Central Utah Water Conservancy District collected and provided all of the data for my research using their field data collection protocol. Deer Creek data were used from April to November from 2005 to 2010 . The field protocol took water samples for algae at specific depths in the water column with samples at the surface, the secchi depth, two-times the secchi depth, and three-times the secchi depth. The first two (upper euphotic zone) and last two samples (lower euphotic zone) were mixed and sent to the laboratory for analysis. Due to the mixing of the algae samples, I hypothesize that the correlations between algae and probe-measured chlorophyll-a will be weak because it is difficult to determine which probe reading should be compared to the laboratory sample results. Ideally, the probe readings and the laboratory samples should come from the same reservoir location, depth, and time.

In this study, I also evaluate the current sampling protocol and recommend modifications to it for Deer Creek Reservoir in an effort to develop better correlations. If adequate correlations between the probe field measurements and laboratory measurements can be validated, then the high resolution probe data can be used with more confidence to manage the reservoir operations. 


\subsection{Scope}

The data collected and used in my research apply specifically to Deer Creek Reservoir. The analysis results will be used to help agencies such as the Bureau of Reclamation and the Central Utah Water Conservancy District better predict algae growth in the reservoir and improve its water quality for drinking and recreation. While this study is specific to Deer Creek reservoir, the general findings are applicable to the larger field of reservoir monitoring and management. This is also true of the sampling protocol evaluation, since this general protocol is used extensively on Utah reservoirs. 


\section{METHODS}

\subsection{Sampling Locations}

The field chlorophyll-a and algae data from Deer Creek Reservoir used in this study were collected and provided by the Central Utah Water Conservancy District. These data were collected monthly between April and November from 2005 to 2010. Measurements were taken at four sampling locations titled: Above Dam, Midlake, Upper End, and Wallsburg Bay. These locations are shown in Figure 2.1. The sampling locations were chosen in accordance with the Clean Lakes Program as part of the Clean Water Act. This requires that water samples on lakes and reservoirs be taken near major inflows, at the deepest points, in the middle, and near any potential source of pollution (OECD 1982).

The equipment below was used to take chlorophyll-a measurements and algae samples:

- Boat

- Handheld Data Collector

- Hach Hydrolab Multi-sensor probe

- Chlorophyll-a optical sensor

- 4 to 6 one liter laboratory bottles per site

- Van Dorn horizontal sampling bottle

- Secchi disk 


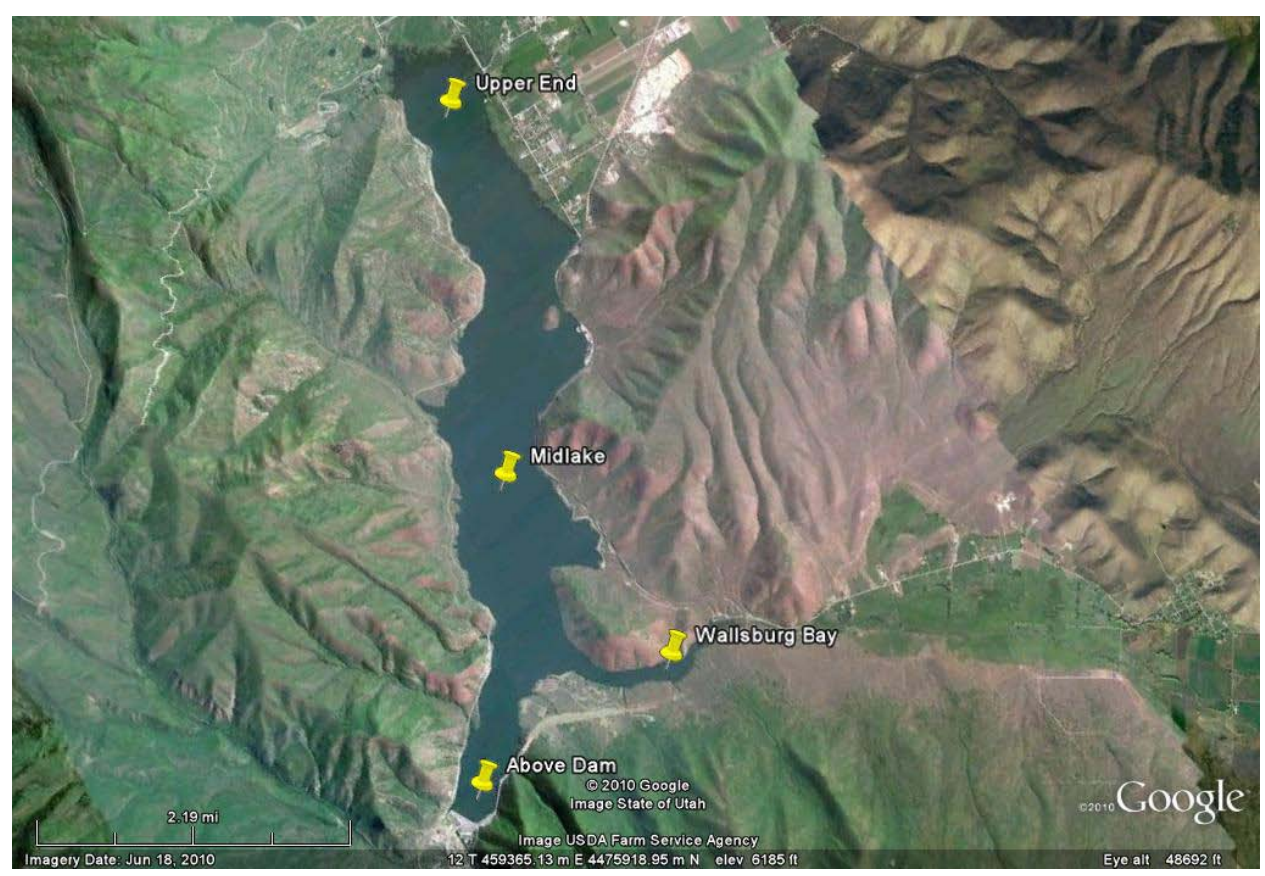

Figure 2.1: Sampling locations on Deer Creek Reservoir (Google Earth Image)

\subsection{Algae}

Water samples for algae analysis were taken from the upper and lower euphotic zones at all four sites in the reservoir. The euphotic zone is the uppermost layer of the lake and is defined as the depth to which light penetrates (Office of Wetlands 2010). The extents of these zones were determined by measuring the secchi depth using a standard secchi disk. In the sampling protocol, the upper euphotic zone is defined at the water column between the water surface and the secchi depth. The lower euphotic zone is defined as the water column between the secchi depth and three-times ( $3 x)$ the secchi depth. Figure 2.2 shows a diagram of the upper and lower euphotic zones and Figure 2.3 shows a diagram of where these zone is located in a lake or reservoir. 


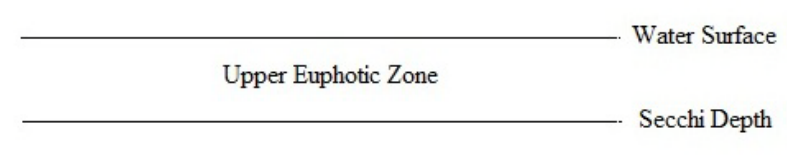

Lower Euphotic Zone

$3 \mathrm{x}$ Secchi Depth

Bottom

Figure 2.2: Figure showing the different sections of the euphotic zone

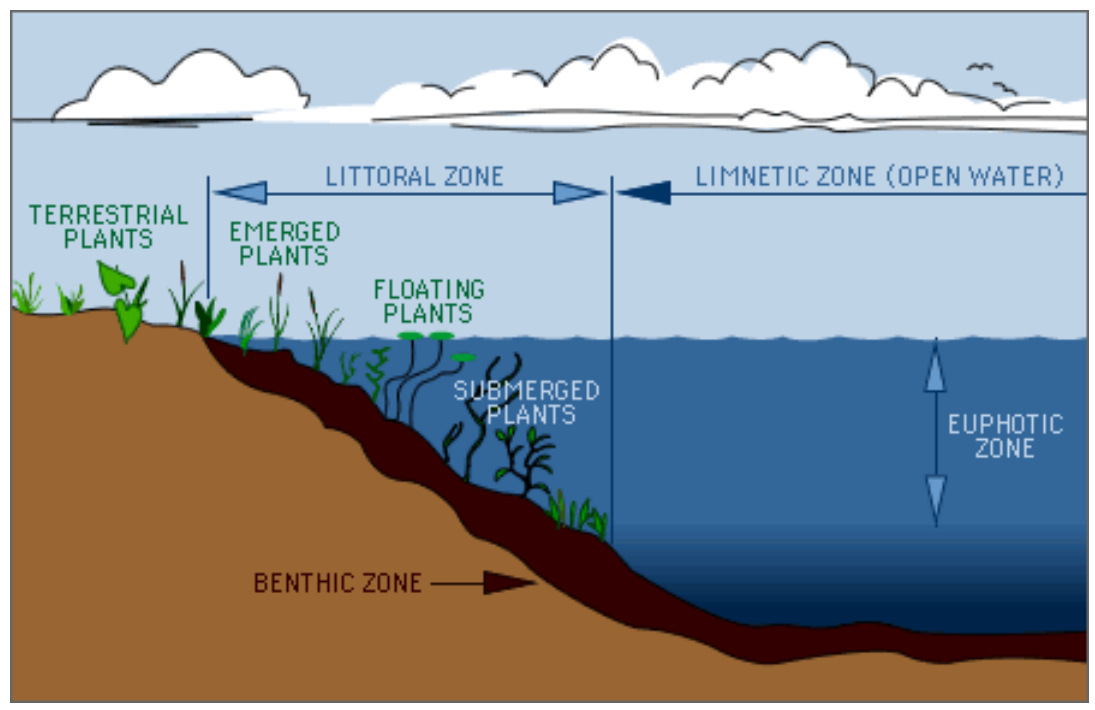

Figure 2.3: Image showing the location of the euphotic zone in a lake or reservoir (Association 2010)

To characterize the algae in the upper euphotic zone, a one-liter sample was taken at the surface and another taken at the secchi depth. These two samples were then mixed in a single 2liter bottle to represent conditions in this zone. This sample was then analyzed in the laboratory. To define the lower euphotic zone, a one-liter water sample was taken at $2 \mathrm{x}$ the secchi depth and 
another taken at $3 \mathrm{x}$ the secchi depth. These samples were also mixed in a single 2-liter bottle to represent this zone, which was then analyzed by the laboratory. A single 2-liter water sample was taken near the reservoir bottom at the Above Dam location to characterize algae in the bottom zone. The Central Utah Water Conservancy District assumed that mixing the water samples in each zone would represent the average algae content in each zone.

These water samples were sent to Rushforth Phycology laboratory to determine the amount of algae in the water as biovolume by using microscopy cell counting methods and chlorophyll using standard extraction techniques. The laboratory results provided algae biovolume in cubic micrometers per milliliter for total phytoplankton and the data were also subdivided into algal phylum or species. The cell counts were performed according to current standard methods (Rushforth and Rushforth 2005).

A separate sample was taken for laboratory chlorophyll-a extraction. This sample was a 2-meter composite sample taken at the surface. The composite sample was well mixed and then a laboratory sample bottle was filled from the sampler. This sample was then analyzed for chlorophyll-a concentration using standard extraction methods. Chlorophyll-a extraction results were reported as micrograms per liter $(\mu \mathrm{g} / \mathrm{l})$.

In addition to taking the water samples, the sampling team used a Hach Hydrolab probe and a Turner Designs sensor to perform field optical measurements of chlorophyll-a every meter in the profile of the reservoir. These data provide a high-resolution measurement of chlorophylla distributions.

The field measurements were stored on a handheld data collector and uploaded to a spreadsheet for analysis and archiving. The sensor measures chlorophyll-a by fluorescence. It emits a blue light at $460 \mathrm{~nm}$ wavelengths into the water. When the blue light comes in contact 
with chlorophyll, it is absorbed. The chlorophyll then fluoresces a red light at $685 \mathrm{~nm}$. The intensity of the red light is read by sensor and converted to chlorophyll-a concentration (Wetzel 2001).

\subsection{Chlorophyll-a and Algae Measurement Correlations}

To compare laboratory-measured algae biovolume to field-measured chlorophyll-a concentrations, I explored two methods for estimating the chlorophyll-a probe measurement in the upper and lower euphotic zones. This was required because water samples were taken at two separate depths and mixed. In addition the depths where the water samples were taken did not necessarily correspond to 1-meter interval locations where the probe readings were made. For the first method, since the water samples were taken to represent average algae, I averaged all of the chlorophyll-a concentrations probe measurements in each zone. For example, if the lower euphotic zone, from secchi depth to $3 \mathrm{x}$ secchi depth, extended over 4 meters, then all four or five probe readings in this zone were averaged to obtain a single value. This value was then paired with the laboratory value that was a result of mixing samples from the $2 \mathrm{x}$ secchi depth and the $3 \mathrm{x}$ secchi depth. However, as shown in Figure 2.4, since the algae samples were taken at two discrete points near the extents of the upper and lower euphotic zones, the average of the probemeasured chlorophyll-a concentration through a zone was not necessarily representative of the laboratory algae sample used to represent the zone. Preliminary results showed very poor correlations using this method and therefore, this method for pairing field-measured chlorophylla to laboratory-measured algae was not used in the results of my research.

For the second method, I used field-measured chlorophyll-a concentrations, from the nearest depths to the water samples. For the upper and lower euphotic zones, two probe- 
measured chlorophyll-a concentrations were averaged for each zone and paired with the respective laboratory algae data. For the upper euphotic zone I averaged the surface and secchi depth probe measurements (as the water sample was a combined sampled from these two points). For the lower euphotic zone I averaged the secchi depth and 3x secchi depth measurements to match the water samples used for this zone.

For the data analysis I had assumed that the water samples were at secchi depth and $3 \mathrm{x}$ secchi depth for the lower euphotic zone and I used the corresponding closest probe measurement. After analysis was complete I learned that the samples were at $2 x$ secchi depth and 3x secchi depth. I did not re-do the analysis because based on visual examination of some example data. It appeared that using a slightly different probe measurement would not have a significant impact. I used an average of the two deepest probe measurements to represent the bottom zone for the Above Dam location. Sampling depths in the water column used for my analysis are shown in Figure 2.4. The actual sampling depths are shown in Figure 4.1 Figure 2.4 shows how the discrete water samples analyzed in the laboratory do not necessarily represent the algae present in each zone as represented by the probe-measured profile of chlorophyll concentrations. Figure 2.5 provides a flow chart of the methods I used to prepare the data for analysis as described above.

\subsection{Data Analysis}

I analyzed the correlation between laboratory-measured biovolume and field-measured chlorophyll-a using laboratory data for total phytoplankton, diatoms, green algae, and blue-green algae. The three algae species, diatoms, green algae, and blue-green algae will also be referred to as diatoms, chlorophyta, and cyanophyta, respectively. I used biovolume measurements as an 


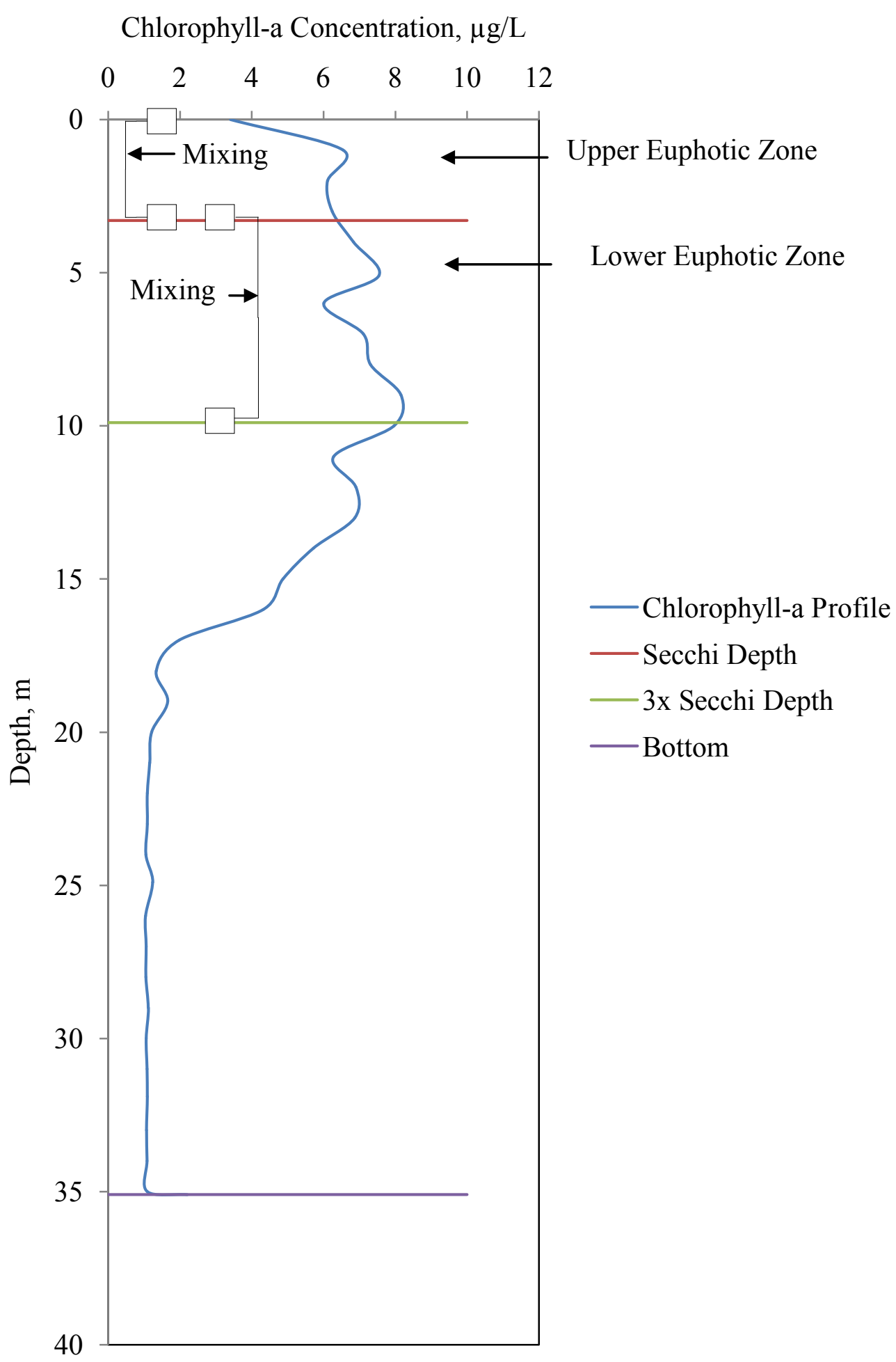

Figure 2.4: A chlorophyll-a profile at the Above Dam site showing the locations water samples were taken. The boxes represent the locations of the algae samples. Mixing of the samples is shown by the lines connecting the boxes both the upper and lower euphotic zone. 


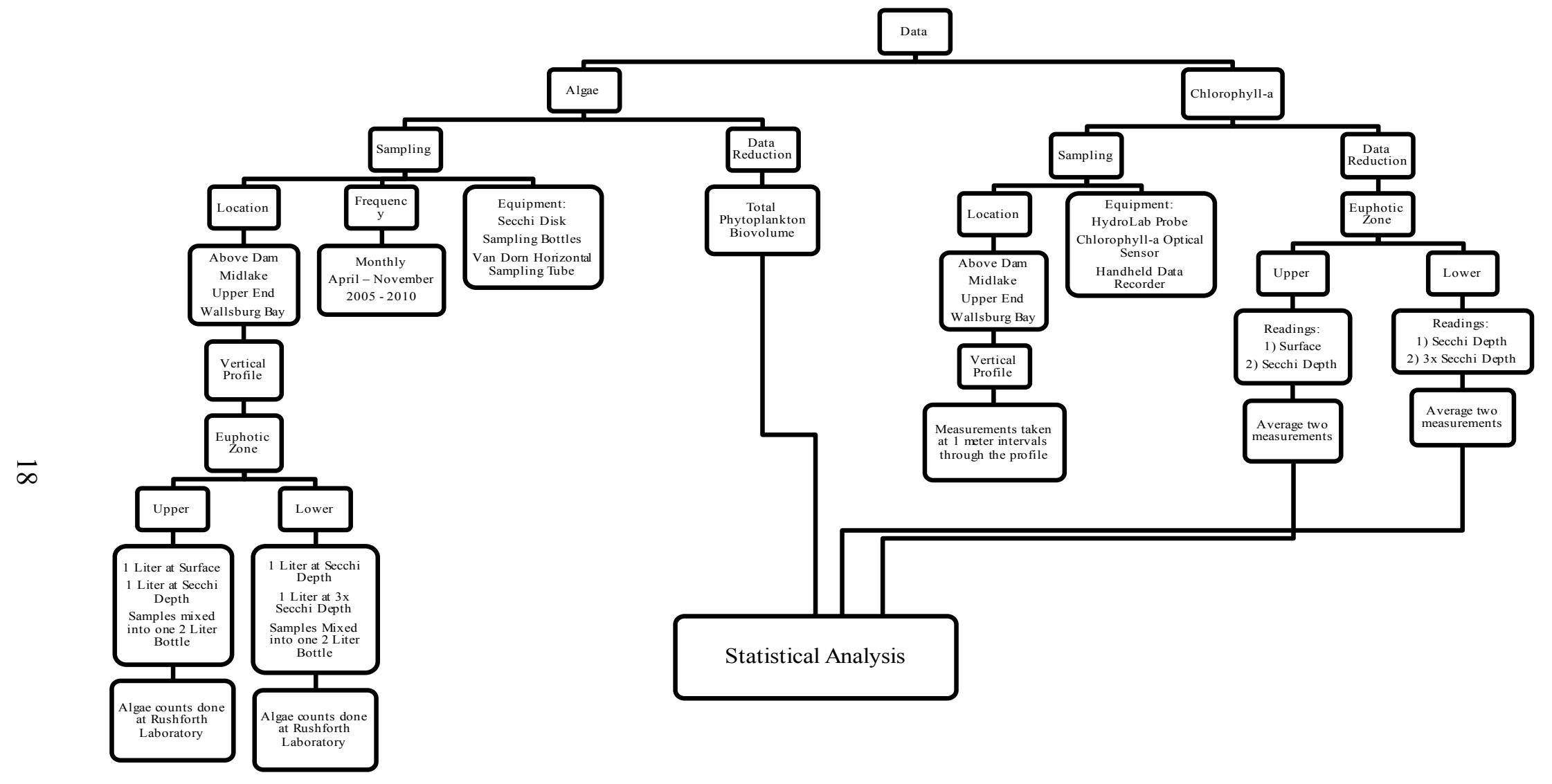

Figure 2.5: Flow chart of sampling and data reduction for algae and chlorophyll-a 
index for biomass (Canfield Jr, Linda et al. 1985). I also noted some issues with using a small number of samples to define algae distributions in a reservoir as alluded to in the discussion on sampling.

A separate regression analysis was done for each zone with field-measured chlorophyll-a as the dependent variable and laboratory-measured algae biovolume as the independent variable. Only linear fits for each data set were evaluated. I used the Statistical Discovery Software JMP in this study to help manage and compute the best fit for the data.

Separate regression analyses were done for each of the four sites on the reservoir in both the upper and lower euphotic zones; at the Above Dam site an additional analysis was done for the bottom samples. As noted, the following algae groups were evaluated: total phytoplankton, chlorophyta, cyanophyta, and diatoms. These algae groups were chosen based on the history of Deer Creek Reservoir and the dominant types of algae present in the samples used in this study (Gaufin and McDonald 1965; David Eckhoff, Alane Boyd et al. 2002). All data pairs from the six years were plotted for each site.

Time-concentration plots for field-measured chlorophyll-a over the six years were also evaluated to determine any temporal trends by observation. This was done in both zones for all four sampling sites. Time-concentration plots for field-measured chlorophyll-a, by the upper and lower euphotic zones, from 2009 to 2010 were also compared to those of time-concentration plots of the algae biovolume data to evaluate any relationship in the trends. The chlorophyll-a concentration to algae biovolume ratios were evaluated to determine if chlorophyll-a concentrations was affected by algae biovolume and what algae species had the most affect. Figure 2.6 shows a flow chart for statistical analysis done in this study. 


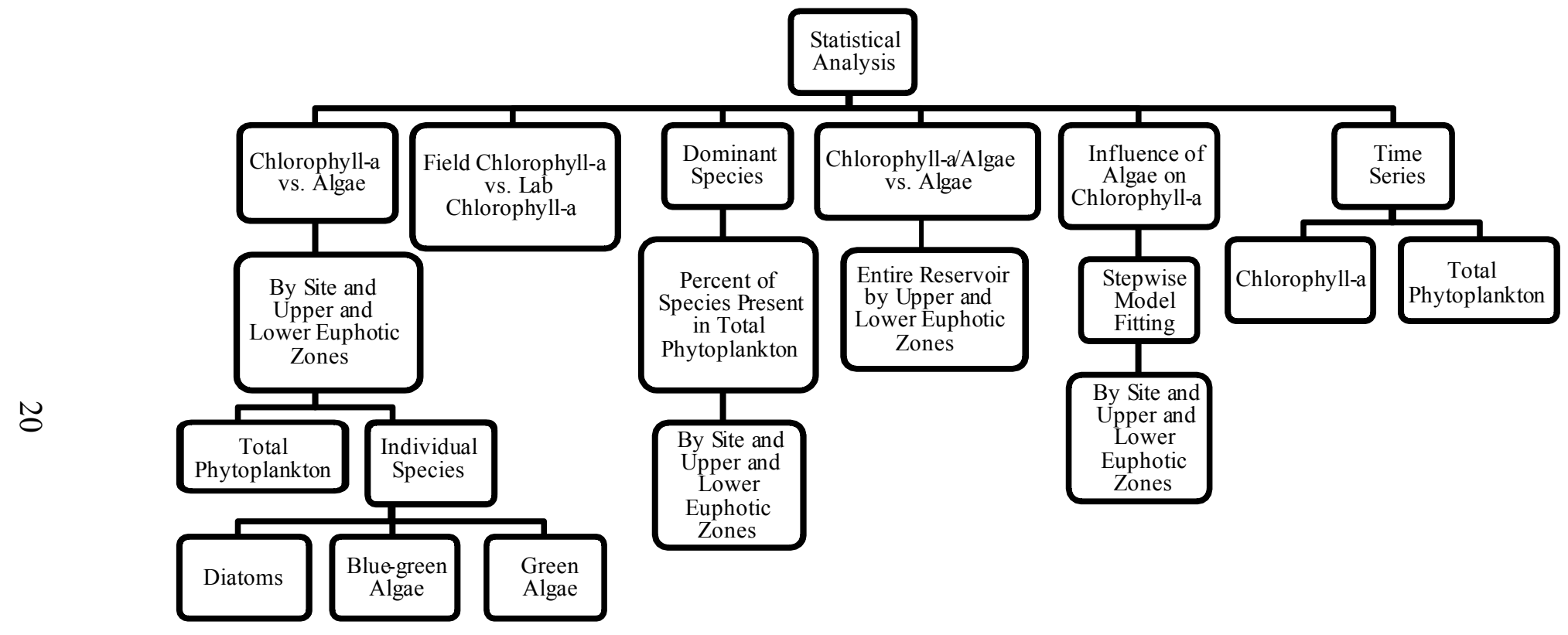

Figure 2.6: Flow chart for the statistical analysis done in this study 


\section{RESULTS}

The results from the data analysis show weak correlations between laboratory-measured phytoplankton biovolume and field-measured chlorophyll-a. The laboratory-measured diatoms and total phytoplankton show the best linear correlation with the field measurements in all three zones at each site. Correlations for green and blue-green algae with the probe data either exhibited different patterns or had weak linear correlations. These correlations are believable because the diatoms are the dominate algae species at most sites on the reservoir and in each section of the euphotic zone. Since diatoms are the main contributor to algae biovolume, correlations with the other algae would be weak as the probe does not discriminate among the various algae types and the majority of the signal that the probe would measure would be from the diatoms. Correlations with the other algae may partially be an artifact of how their concentrations are correlated to the diatom concentrations.

\subsection{Above Dam}

Table 3.1 shows that diatoms dominate in all three zones at the Above Dam site. Correlations between total phytoplankton biovolume and field-measured chlorophyll-a as well as diatom biovolume and field-measured chlorophyll-a are shown below. The diatoms showed the best correlation to chlorophyll-a. This may be partially explained by the dominance of the 
diatoms in the biovolume with percentages ranging from $74 \%$ to $96 \%$ in the three zones. Table 3.1 shows the percentage of biovolume for each algae species for each zone at this site.

Table 3.1: Percentage of the amount of algae biovolume for each species found in the upper and lower euphotic zones and at the bottom

\begin{tabular}{lccc}
\hline \multicolumn{1}{c}{ Algae Species } & $\begin{array}{c}\text { Upper Euphotic } \\
\text { Zone }\end{array}$ & $\begin{array}{c}\text { Lower Euphotic } \\
\text { Zone }\end{array}$ & Bottom \\
\hline Chlorophyta & $4.05 \%$ & $2.65 \%$ & $1.10 \%$ \\
Chrysophta & $12.53 \%$ & $9.56 \%$ & $0.01 \%$ \\
Cyanophyta & $6.10 \%$ & $4.93 \%$ & $1.85 \%$ \\
Diatom & $74.0 \%$ & $79.48 \%$ & $96.06 \%$ \\
Dinophyta & $2.77 \%$ & $1.76 \%$ & $0.15 \%$ \\
Euglenophyta & $0.04 \%$ & $0.09 \%$ & $0.08 \%$ \\
Heterokontophyta & $0.26 \%$ & $1.13 \%$ & $0.70 \%$ \\
Streptonphyta & $0.24 \%$ & $0.31 \%$ & $0.05 \%$ \\
Unspecified & - & $0.09 \%$ & - \\
\hline
\end{tabular}

Correlations between diatom biovolume and field-measured chlorophyll-a are the strongest of the relationships, although they are only moderately correlated. No strong, linear correlations were found for any of the other species in the upper euphotic zone including green and blue-green algae. Correlations between total phytoplankton biovolume and field-measured chlorophyll-a were also moderate in strength. Figures 3.1 through 3.3 show the correlations for total phytoplankton, diatoms, and blue-green algae for the upper euphotic zone, respectively.

The same relationships were evaluated for the lower euphotic zone and the bottom at the near dam site. Diatoms showed a similar relationship to that found in the upper zone. The $\mathrm{R}^{2}$ value for diatom correlation to field-measured chlorophyll-a was approximately 0.51 . However, at the bottom the relationship weakened significantly having an $\mathrm{R}^{2}$ value of 0.15 . The strength of the correlation for blue-green algae decreased in the lower euphotic zone and at the bottom, as 
did the percentage of total biovolume represented by the blue-green algae. The $\mathrm{R}^{2}$ values for these two zones were 0.36 and 0.28 , respectively. A negative relationship between green algae biovolume and field-measured chlorophyll-a was found at the bottom.

Total phytoplankton showed similar trends in correlation strength from the lower euphotic zone to the bottom. The lower euphotic zone showed a slight decrease in strength to an $\mathrm{R}^{2}$ value of 0.47 . The bottom showed an $\mathrm{R}^{2}$ value of 0.14 , very similar to that of diatoms. To stress an earlier point, while the correlations with the other algae species are low, these species make up only a small percentage of the total biomass measured by the field probe. I would not expect correlations for these species to be high, unless the species biovolume is correlated to total biovolume.

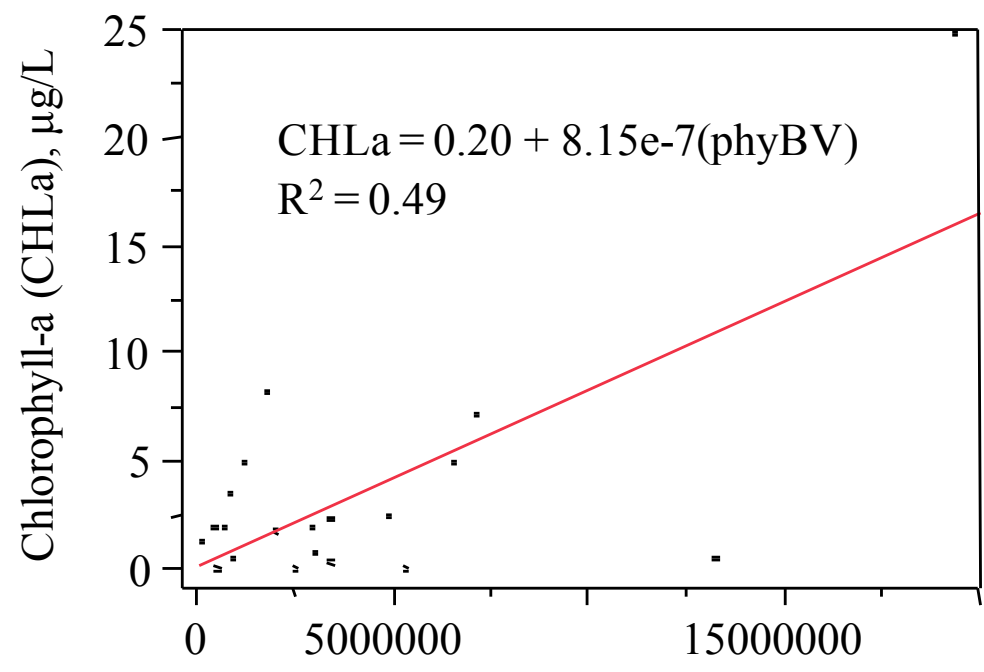

Total Phytoplankton Biovolume (phyBV), $\mu \mathrm{m}^{3} / \mathrm{mL}$

Figure 3.1: Regression results for total phytoplankton from the upper euphotic zone at the Above Dam site 


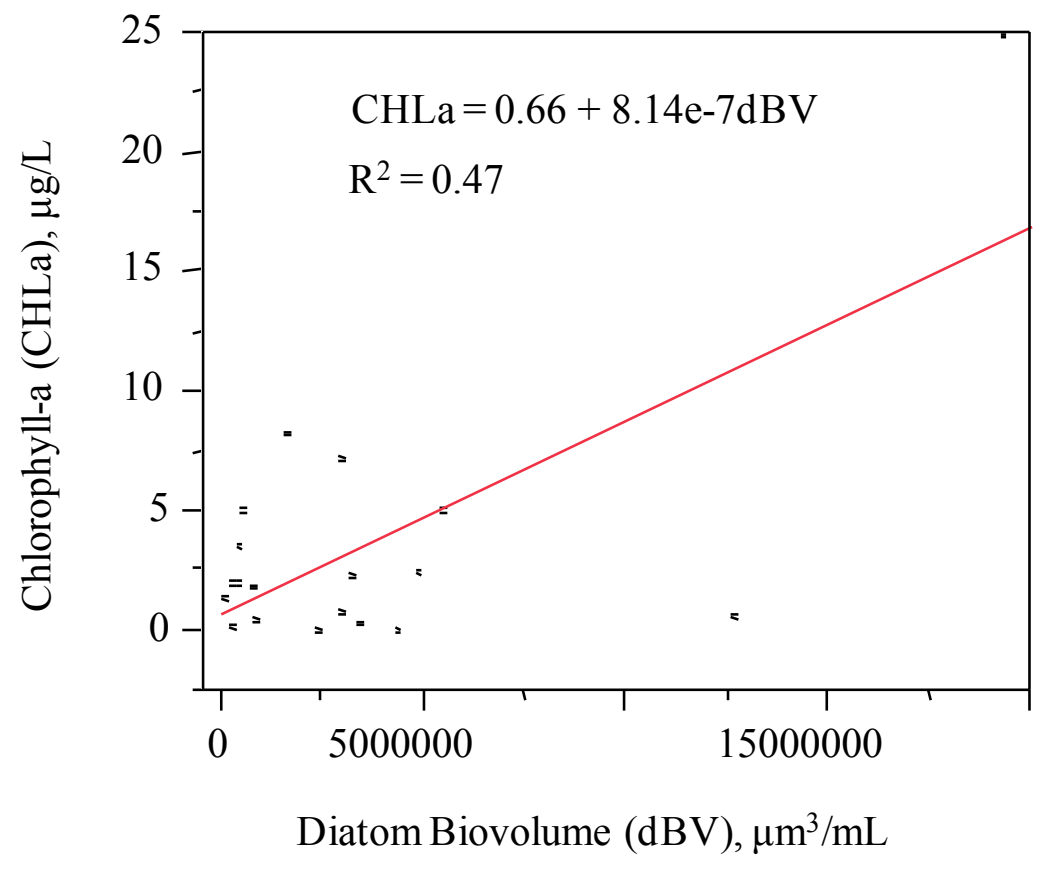

Figure 3.2: Regression results for diatoms from the upper euphotic zone at the Above Dam site

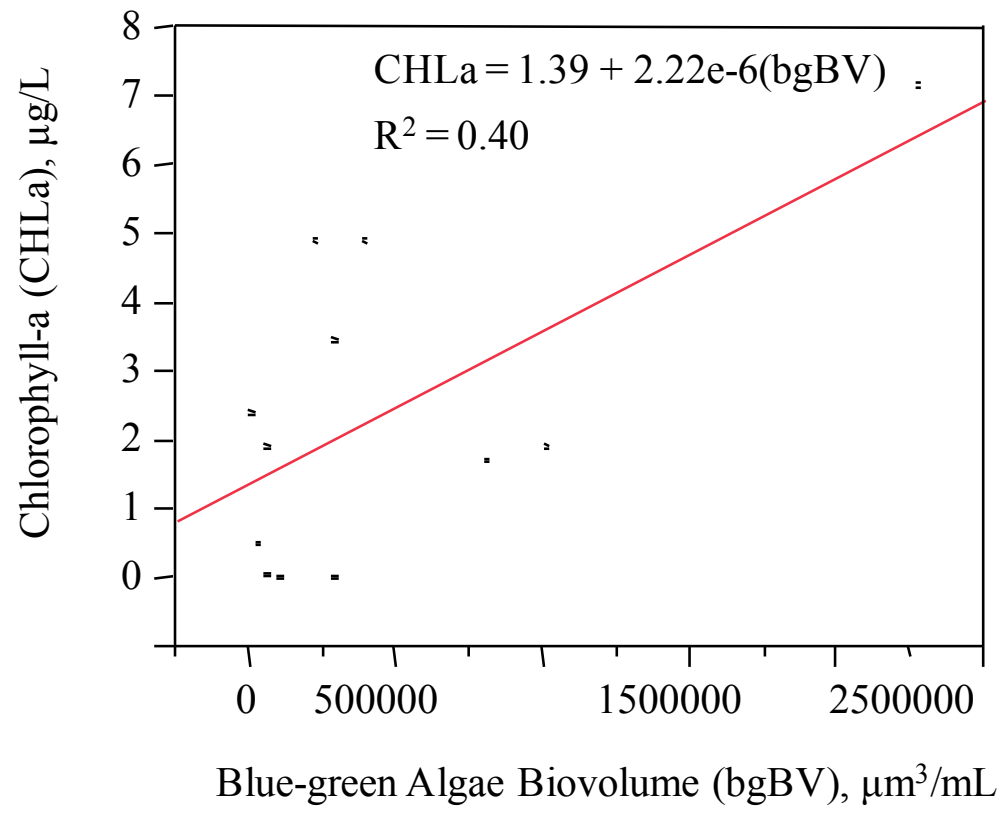

Figure 3.3: Regression results for blue-green algae from the upper euphotic zone at the Above Dam site 


\subsection{Midlake}

Table 3.2 shows the percentage of algae biovolume by species for the Midlake site. Again, diatoms dominated both the upper and lower euphotic zones. However, a third of the algae biovolume in the upper zone is represented by blue-green algae at this site. The relationships between field-measured chlorophyll-a and laboratory-measured total phytoplankton, diatoms, and blue-green algae are shown in Figures 3.4 to 3.6, respectively.

All three comparisons show weaker correlations at the Midlake site than at the Above Dam site. The correlation strength of the total phytoplankton to chlorophyll-a increased to an $\mathrm{R}^{2}$ value of 0.43 in the lower euphotic zone from a value of 0.32 . The diatom correlation in the lower euphotic zone showed similar strength as in that of the upper euphotic zone, with an $\mathrm{R}^{2}$ value of 0.40 . The correlation strength of the blue-green algae with the field-measured chlorophyll-a significantly increased in the lower euphotic zone compared to the upper. The $\mathrm{R}^{2}$ value for blue-green algae as a function of field-measured chlorophyll-a was 0.76 in the lower zone compared to 0.27 in the upper zone.

Table 3.2: Percentage of the amount of algae biovolume for each species found in the upper and lower euphotic zones

\begin{tabular}{lcc}
\hline \multicolumn{1}{c}{ Algae Species } & Upper Euphotic Zone & Lower Euphotic Zone \\
\hline Chlorophyta & $2.47 \%$ & $9.53 \%$ \\
Chrysophta & $7.26 \%$ & $7.86 \%$ \\
Cyanophyta & $33.43 \%$ & $7.68 \%$ \\
Diatom & $49.63 \%$ & $65.83 \%$ \\
Dinophyta & $6.77 \%$ & $7.45 \%$ \\
Euglenophyta & $0.10 \%$ & $0.07 \%$ \\
Heterokontophyta & $0.30 \%$ & $1.40 \%$ \\
Streptonphyta & $0.03 \%$ & $0.14 \%$ \\
Unspecified & - & $0.02 \%$ \\
\hline
\end{tabular}




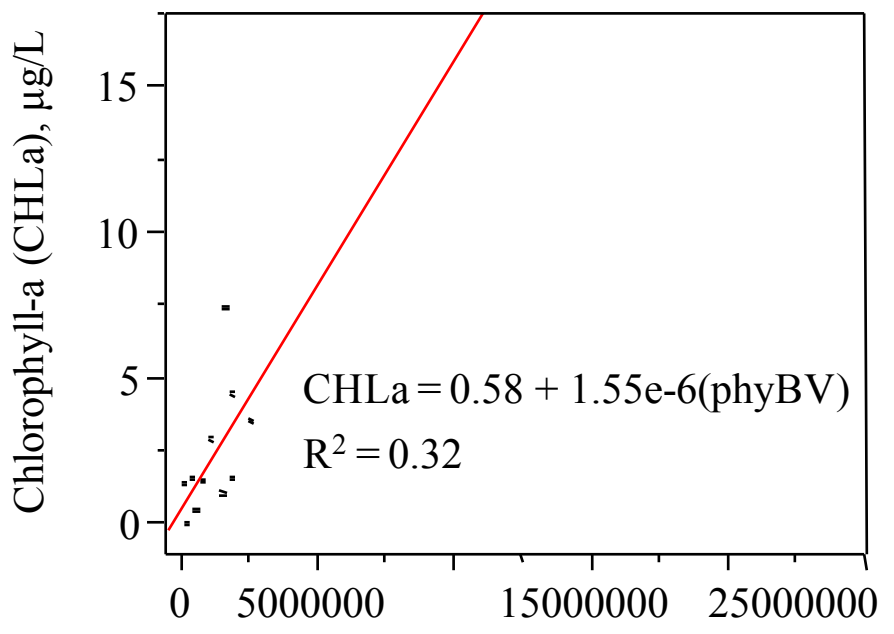

Total Phytoplankton Biovolume (phyBV), $\mu \mathrm{m}^{3} / \mathrm{mL}$

Figure 3.4: Regression results for total phytoplankton in the upper euphotic zone at the Midlake site

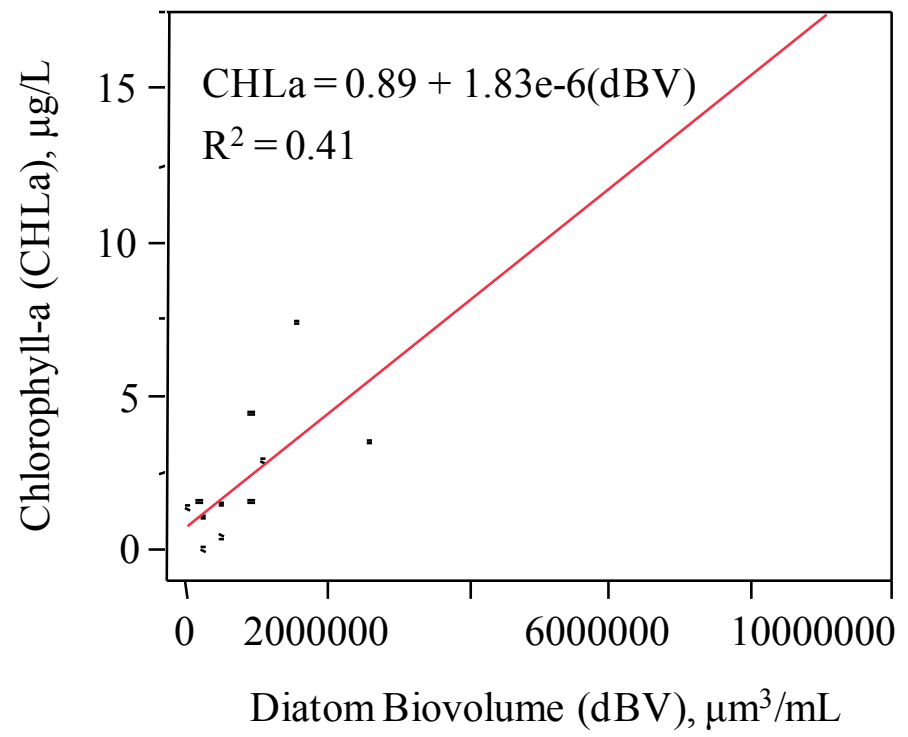

Figure 3.5: Regression results for diatom biovolume in the upper euphotic zone at the Midlake site 


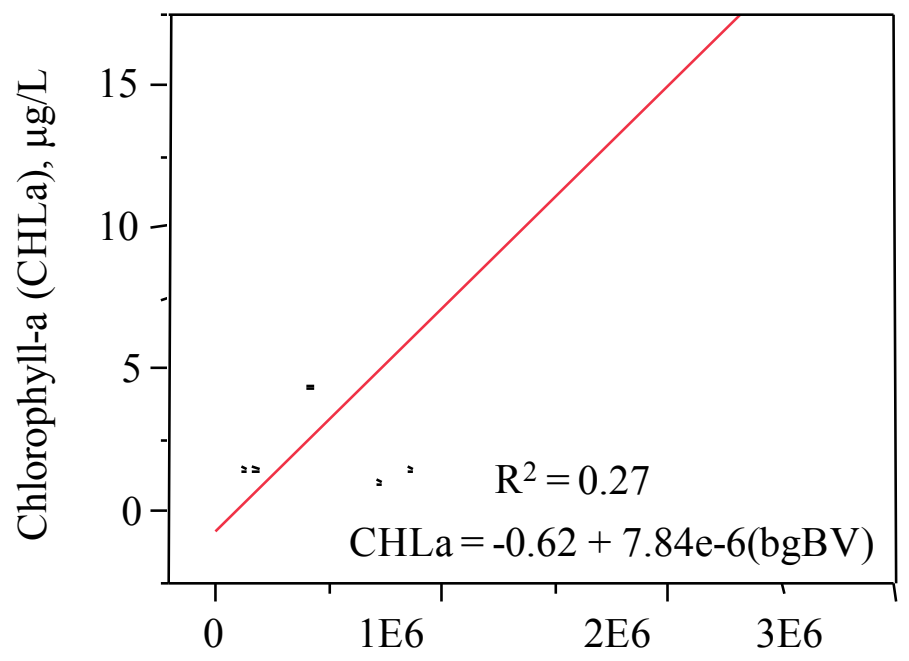

Blue-green Algae Biovolume (bgBV), $\mu \mathrm{m}^{3} / \mathrm{mL}$

Figure 3.6: Regression results for blue-green biovolume from the upper euphotic zone at the Midlake site

\subsection{Upper End}

The dominate algae species at the Upper End site was blue-green algae, which represented almost $50 \%$ of the total phytoplankton biovolume. Diatoms contributed about one third of the total phytoplankton biovolume. The percentage biovolume for each species present at this site is shown below in Table 3.3. As can be seen in Figures 3.7 to 3.9, no strong linear correlations between field-measured chlorophyll-a and total phytoplankton, blue-green algae, or diatoms were found in the upper euphotic zone. The correlations for the same species in the lower euphotic zone were stronger, but still relatively weak. The $\mathrm{R}^{2}$ values for field-measured chlorophyll-a with diatoms, blue-green algae, and total phytoplankton in the lower zone were $0.23,0.32$, and 0.15 , respectively. 
Table 3.3: Percentage of the amount of algae biovolume for each species found in the upper and lower euphotic zones

\begin{tabular}{lcc}
\hline \multicolumn{1}{c}{ Algae Species } & Upper Euphotic Zone & Lower Euphotic Zone \\
\hline Chlorophyta & $3.36 \%$ & $7.29 \%$ \\
Chrysophta & $6.73 \%$ & $1.30 \%$ \\
Cyanophyta & $45.48 \%$ & $11.79 \%$ \\
Diatom & $34.79 \%$ & $70.11 \%$ \\
Dinophyta & $8.91 \%$ & $9.34 \%$ \\
Euglenophyta & $0.20 \%$ & $0.10 \%$ \\
Heterokontophyta & $0.46 \%$ & - \\
Streptonphyta & $0.07 \%$ & $0.07 \%$ \\
Unspecified & - & $0.00 \%$ \\
\hline
\end{tabular}

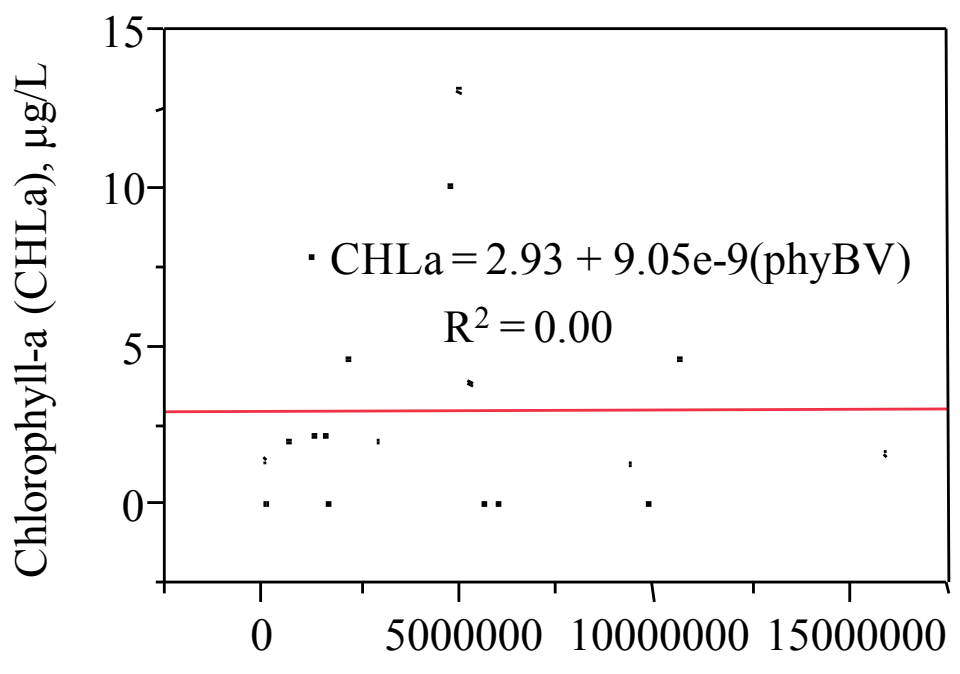

Total Phytoplankton Biovolume (phyBV), $\mu \mathrm{m}^{3} / \mathrm{mL}$

Figure 3.7: Regression results for total phytoplankton in the upper euphotic zone at the Upper End site 


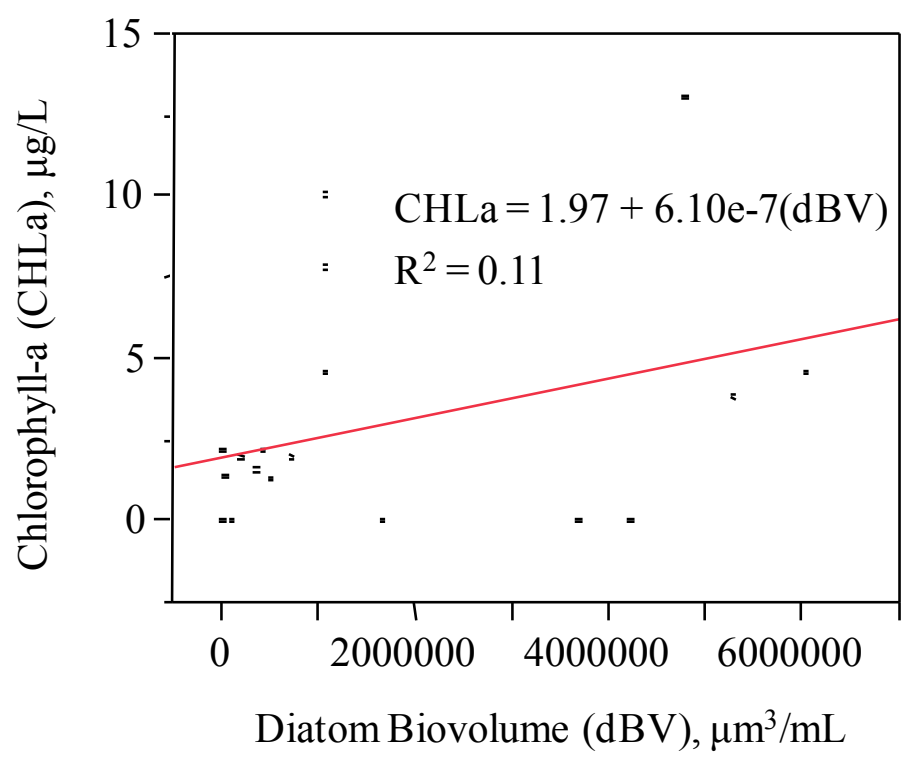

Figure 3.8: Regression results for diatom biovolume from the upper euphotic zone at the Upper End site

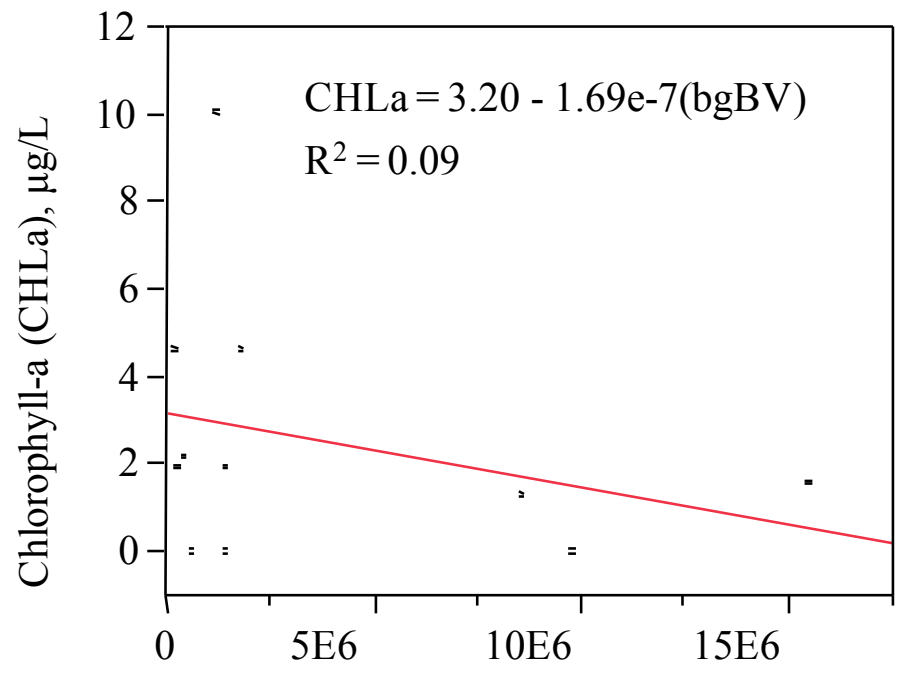

Blue-green Algae Biovolume (bgBV), $\mu \mathrm{m}^{3} / \mathrm{mL}$

Figure 3.9: Regression results for cyanophyta biovolume for the upper euphotic zone at the Upper End site 


\subsection{Wallsburg Bay}

At the Wallsburg Bay site, diatoms dominated in both the upper and lower euphotic zones. Table 3.4 shows the percentage of algae biovolume for each species. This is the percent of the total phytoplankton biovolume. Moderate correlations were observed for field-measured chlorophyll-a with total phytoplankton and diatoms in the upper euphotic zone as shown in Figures 3.10 and 3.11, respectively. However, a weak correlation was observed with blue-green algae as shown in Figure 3.12. The strength of the correlations for total phytoplankton, diatoms, and blue-green algae decreased significantly from the upper euphotic zone to the lower. The $\mathrm{R}^{2}$ values for the correlations were $0.18,0.34$, and 0.01 , respectively.

Green algae were also analyzed in this study for all four sites on Deer Creek and in each zone. At each site and at each level, weak linear correlations were observed. The relationship to field-measured chlorophyll-a, however, exhibited nonlinear distributions in the data when examined visually. Nonlinear relationships were not analyzed in this study.

Table 3.4: Percentage of the amount of algae biovolume for each species found in the upper and lower euphotic zones

\begin{tabular}{lcc}
\hline \multicolumn{1}{c}{ Algae Species } & Upper Euphotic Zone & Lower Euphotic Zone \\
\hline Chlorophyta & $3.51 \%$ & $7.05 \%$ \\
Chrysophta & $8.20 \%$ & $9.89 \%$ \\
Cyanophyta & $6.99 \%$ & $7.29 \%$ \\
Diatom & $78.53 \%$ & $74.67 \%$ \\
Dinophyta & $2.62 \%$ & $1.07 \%$ \\
Euglenophyta & $0.01 \%$ & $0.02 \%$ \\
Heterokontophyta & $0.07 \%$ & $0.00 \%$ \\
Streptonphyta & $0.06 \%$ & - \\
Unspecified & - & - \\
\hline
\end{tabular}




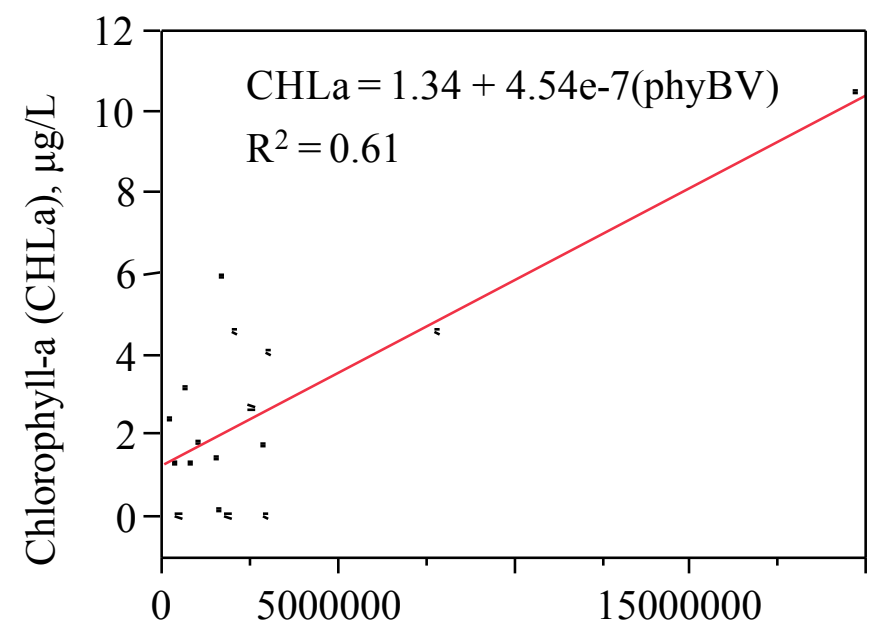

Total Phytoplankton Biovolume (phyBV), $\mu \mathrm{m}^{3} / \mathrm{mL}$

Figure 3.10: Regression results for total phytoplankton in the upper euphotic zone at Wallsburg Bay

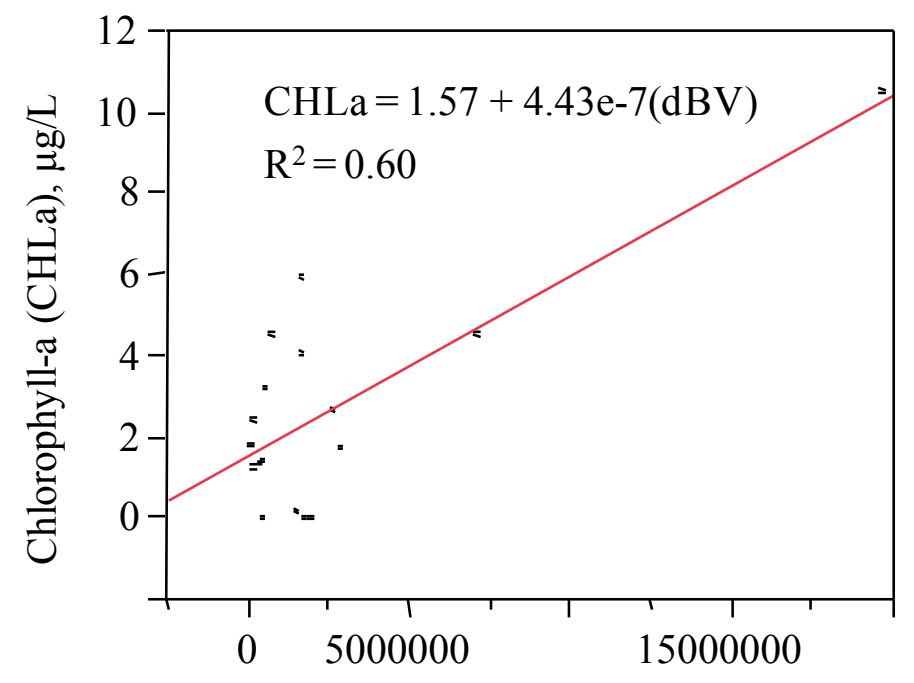

Diatom Biovolume (dBV), $\mu \mathrm{m}^{3} / \mathrm{mL}$

Figure 3.11: Regression results for diatom biovolume in the upper euphotic zone at the Wallsburg Bay site 


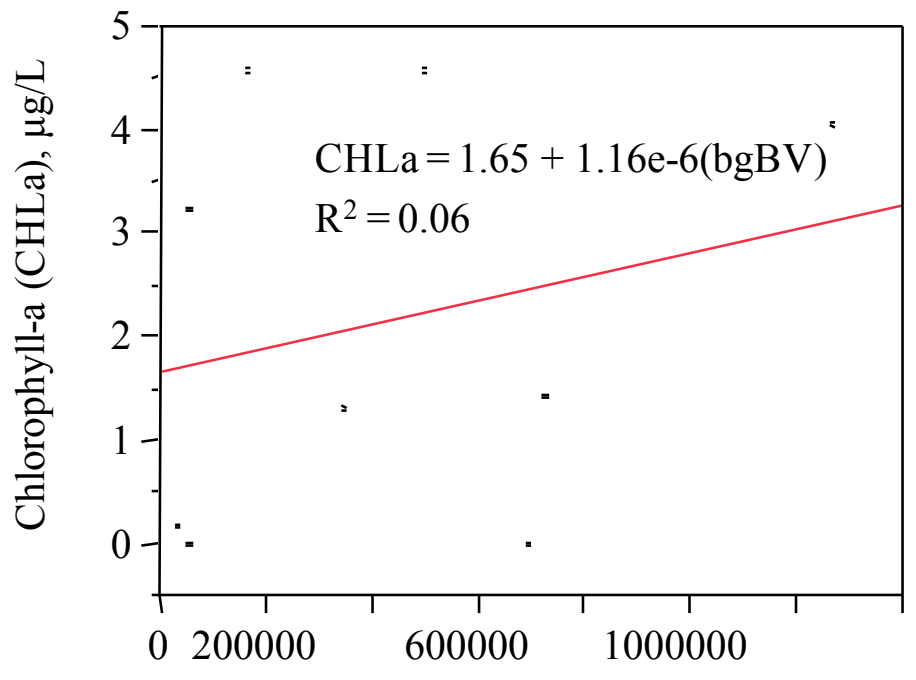

Blue-green Algae Biovolume (bgBV), $\mu \mathrm{m}^{3} / \mathrm{mL}$

Figure 3.12: Regression results for cyanophyta biovolume in the upper euphotic zone at Wallsburg Bay

\subsection{Laboratory Chlorophyll}

In addition to exploring the correlations between field-measured chlorophyll and laboratory-measured biomass, I also compared field-measured chlorophyll with laboratory measured chlorophyll. As noted earlier, the samples used for laboratory-measured chlorophyll were taken from a two-meter composite sampling tube. However, there were some issues with being able to directly match field measurement locations with laboratory samples. This correlation was done to determine the accuracy of the field optical chlorophyll-a sensor. However, the field measurement measures chlorophyll that is still contained within algae cells and not completely exposed to the probe's light beam. The laboratory measurement first extracts the chlorophyll from the cells then uses optical transmission techniques to determine the concentration. Based on this, I did not expect the measurements to directly correlate. 
The comparison was done by comparing chlorophyll-a measurements from the sensor to laboratory measurements at the similar depths, times, and locations. The chlorophyll-a samples measured in the laboratory were taken as a composite sample from the water surface to a depth of 2 meters using a PVC pipe. The probe readings at zero, one, and two meters were averaged and paired with the laboratory data for comparison. Figure 3.13 shows the results of this comparison. A strong correlation was observed between the lab measurements and the probe measurements, though as expected the correlation was not 1:1.

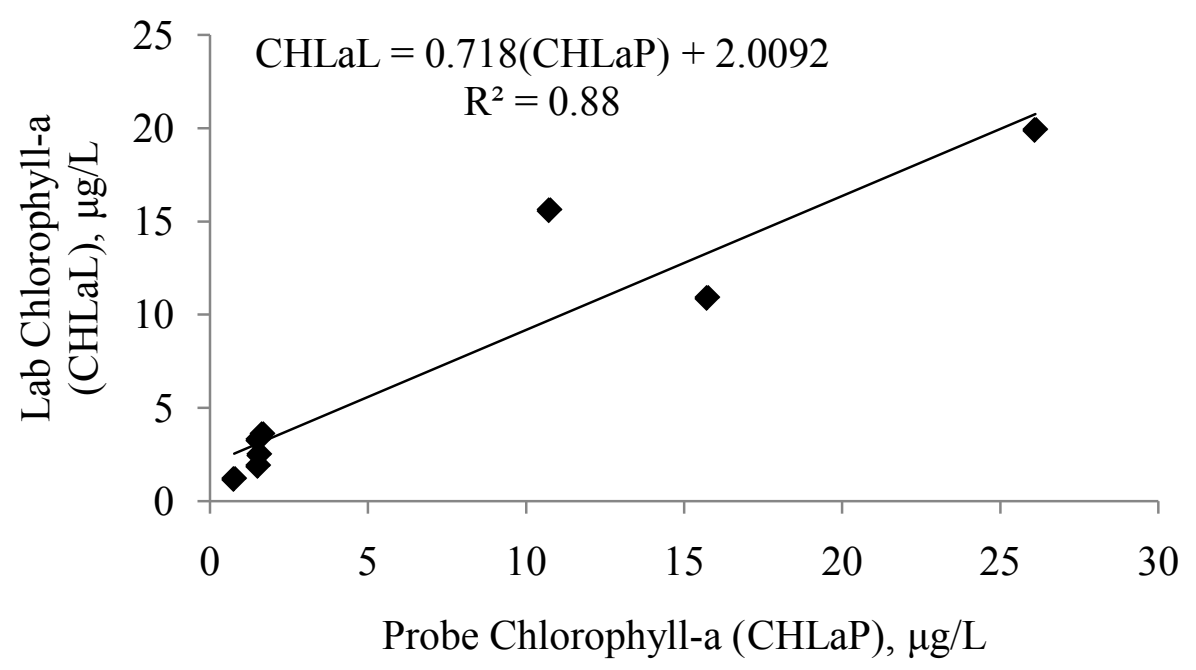

Figure 3.13: Relationship between lab chlorophyll-a measurements and probe chlorophyll-a measurements

The chlorophyll-a laboratory measurements were also compared with the laboratory measured diatom biovolume to determine if there was any correlation. Diatom biovolumes from the upper euphotic zone of the Above Dam, Midlake, and Upper End sites were used in this comparison. Figure 3.14 show that there is a strong correlation between diatoms and chlorophyll-a laboratory measurements with an $\mathrm{R}^{2}$ value of 0.92 . The relationship between the 
probe-measured chlorophyll-a, taken as the average value at 0,1 , and 2 meters deep, and diatoms was also investigated. This relationship showed an $\mathrm{R}^{2}$ value of 0.87 and is presented in Figure 3.15

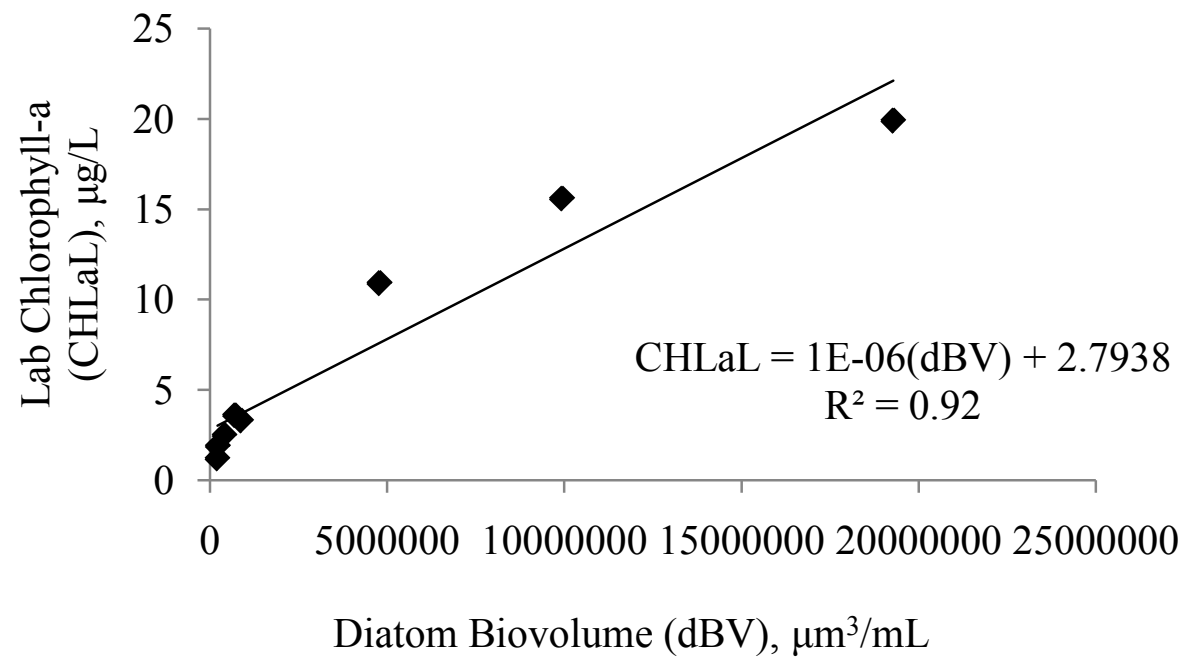

Figure 3.14: Correlation between lab chlorophyll-a measurements and diatom biovolume for the upper euphotic zone at the Above Dam, Midlake, and Upper End sites

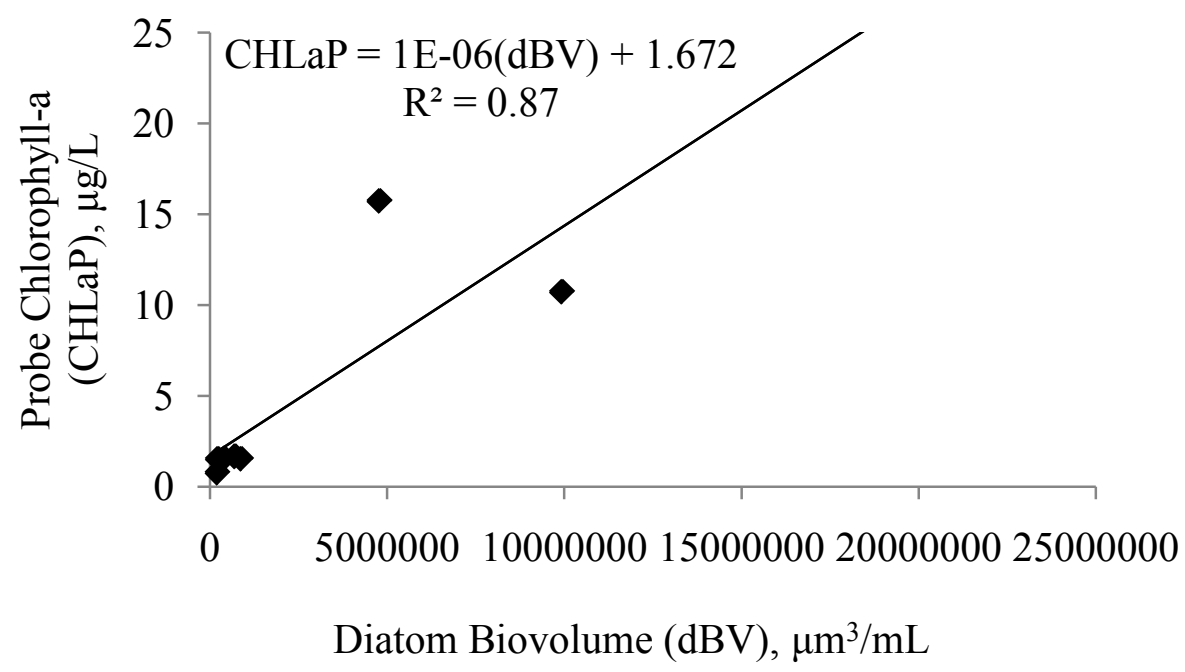

Figure 3.15: Correlation between probe chlorophyll-a measurements and diatom biovolume for the upper euphotic zone at the Above Dam, Midlake, and Upper End sites 


\subsection{Cell Volume and Chlorophyll Relationships}

The amount of the apparent chlorophyll-a present for field measurement may change with increasing biovolume (Desortová 1981; Felip and Catalan 2000) and may be causing some issues with the field-measured data for both the green and blue-green algae. Figure 3.16 and Figure 3.17 show plots of the ratio of chlorophyll-a mass to algae cell volume by total phytoplankton biovolume for the upper and lower euphotic zone, respectively. The values on the y axis were calculated by dividing chlorophyll-a concentration by total phytoplankton biovolume. The units for volume of water cancel, leaving mass of chlorophyll-a per algae cell volume. The data includes points from the entire reservoir. The results show that as algae biovolume increases, the amount of chlorophyll-a per algae cell volume tends to decrease. Similar results were observed for each species.

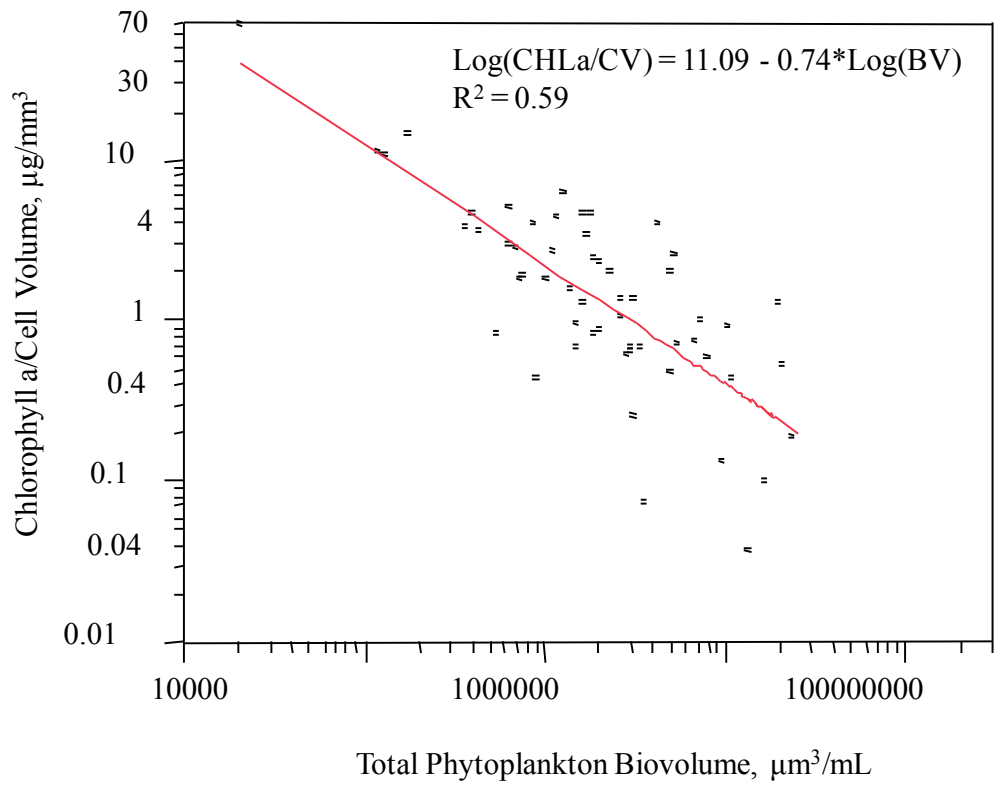

Figure 3.16: Chlorophyll-a mass to cell volume ratio relationship with total phytoplankton biovolume for the upper euphotic zone on Deer Cree Reservoir 


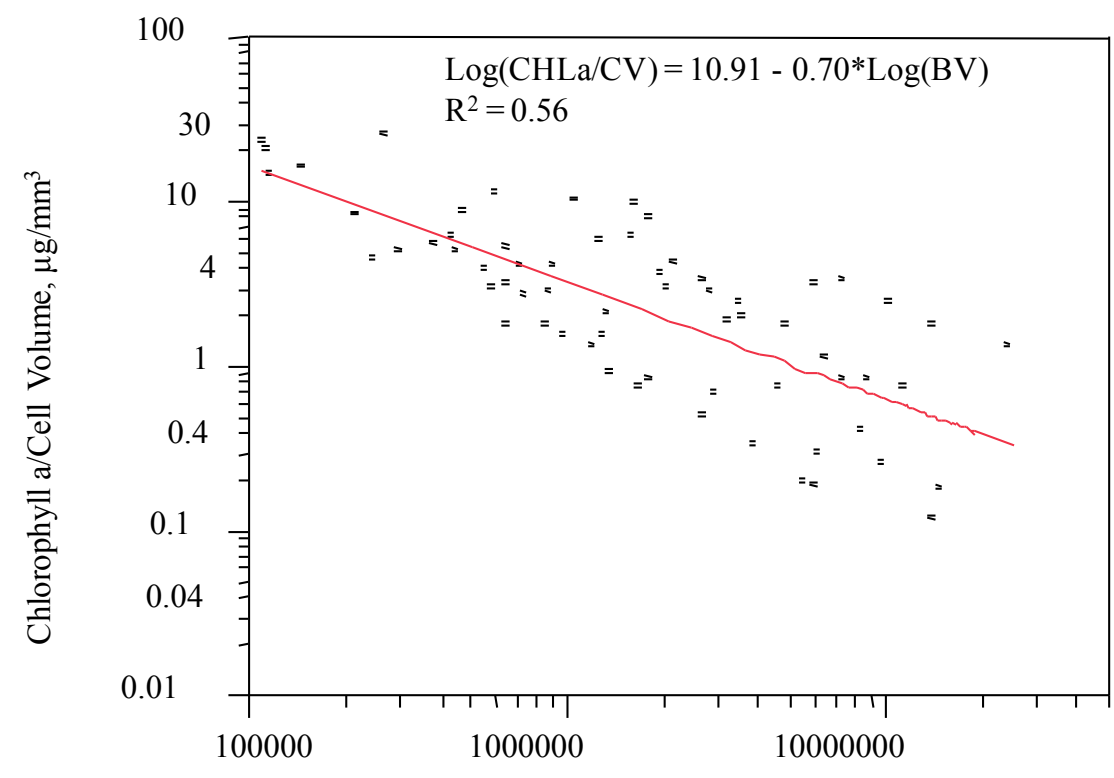

Total Phytoplankton Biovolume, $\mu \mathrm{m}^{3} / \mathrm{mL}$

Figure 3.17: Chlorophyll-a mass to cell volume ratio relationship with total phytoplankton biovolume for the lower euphotic zone on Deer Cree Reservoir

Similar trends were also observed when the data were plotted according to sampling locations on the reservoir. Figures 3.18 and 3.19 show chlorophyll-a concentration and total phytoplankton biovolume time series from May 2009 to November 2010 for the upper and lower euphotic zones at the Upper End site, respectively. In both zones, the ratio of chlorophyll-a to biovolume changes throughout the year. The ratio not only decreases, but also increases depending on the time of year. This agrees with Desortova's observations that chlorophyll-a content per unit biomass, in this case biovolume, is not constant (Desortová 1981), but fluctuates throughout the year.

These data show that the poor correlations observed in the regression analysis, can be related to a change in chlorophyll-a concentrations per cell volume. For example, when the reservoir turns over, the water at the surface sinks to the bottom and the water at the bottom 


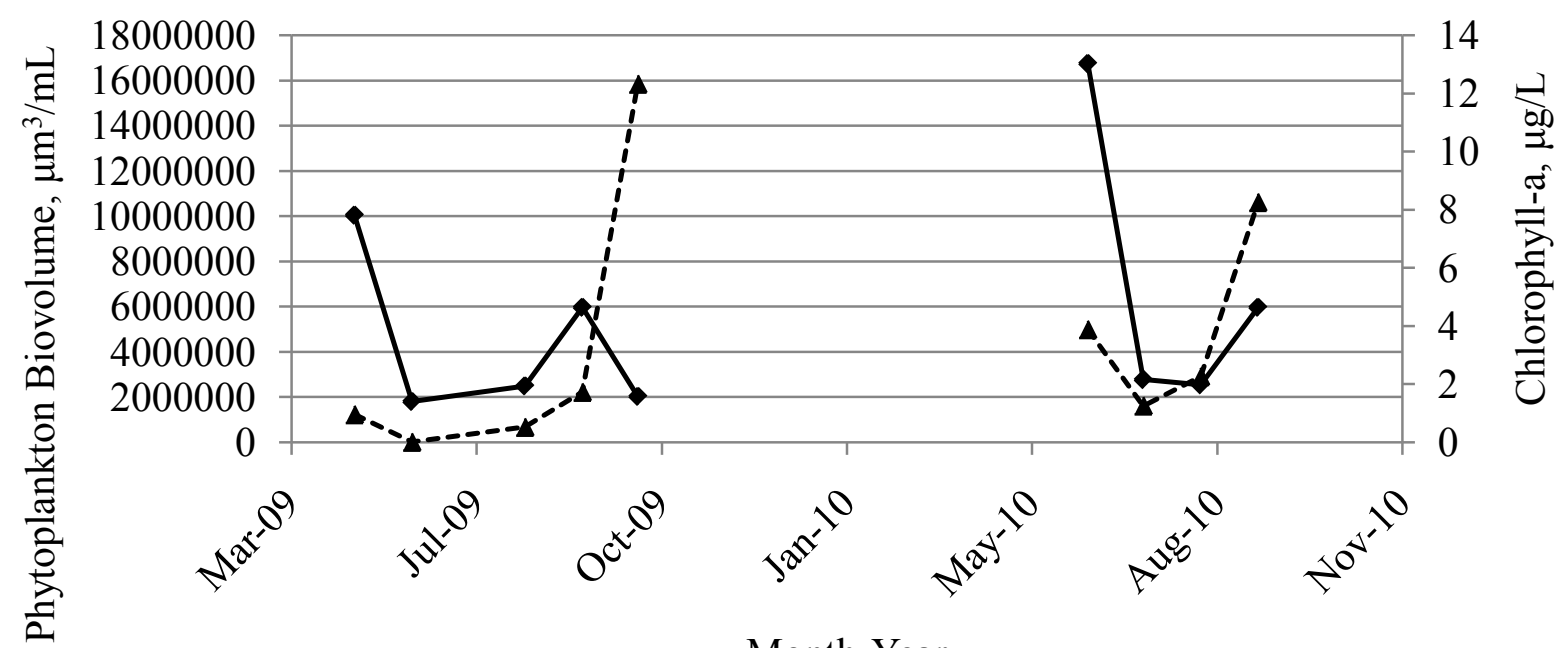

--^--Phytoplankton Biovolume $\longrightarrow$ Chlorophyll-a

Figure 3.18: Chlorophyll-a concentration and phytoplankton biovolume time series at the Upper End site in the upper euphotic zone in 2009 and 2010

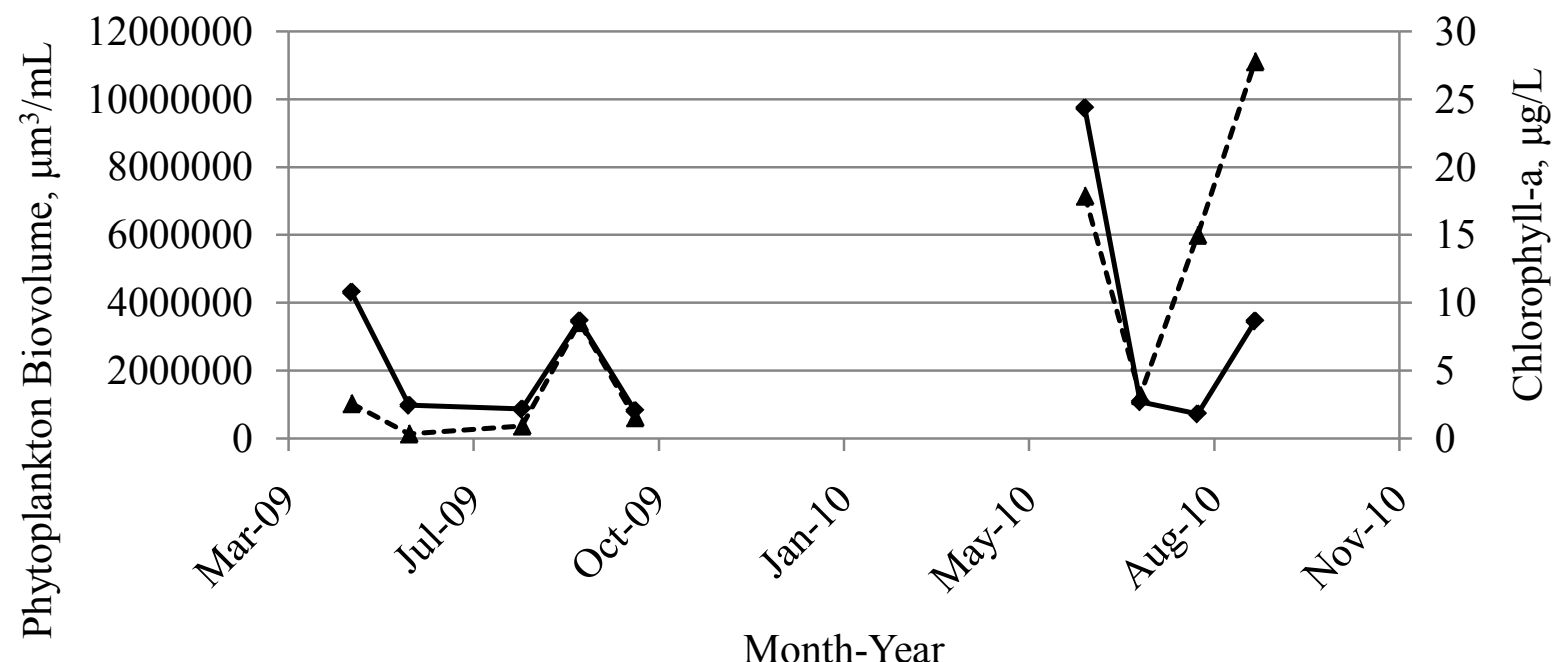

--^--Phytoplankton Biovolume $\longrightarrow$ Chlorophyll-a

Figure 3.19: Chlorophyll-a concentration and phytoplankton biovolume time series at the Upper End site in the lower euphotic zone in 2009 and 2010 
moves up towards the surface. When this happens, dead material at the bottom of the reservoir can be transported to near the surface. The material may include dead algae cells, containing no chlorophyll. In this case, there is a high concentration of algae biovolume with a low concentration of chlorophyll. This sudden change in the ratio between chlorophyll and algae cell volume could have had an effect on my results. However, more studies must be done in order to quantify that effect.

The variation in chlorophyll-a to biovolume ratio can be explained by variations in nutrient loadings, seasonal changes, water and air temperature, wind, and turbidity. Figure 3.20 shows time series concentrations for several different water quality parameters measured on the reservoir in 2010. Dissolved oxygen (LDO), nitrate (NO3-), phosphate, and turbidity show similar trends to the chlorophyll-a measurements. This indicates that there could be a relationship between either one or all of these parameters with chlorophyll-a.

Additional research is required to discover what these relationships are and how strong they are. However, the preliminary information from this time series does indicate that chlorophyll-a concentration in Deer Creek is affected by the variables shown in Figure 3.20.

Many other studies on the effect nutrients, temperature, mixing, exposure to light, light intensity, turbidity water currents in the reservoir, algal cell age, the health of the cell, and different algal species have on chlorophyll-a concentrations have been done and show that there is a relationship (Gaufin and McDonald 1965; Kiefer 1973; Jones and Bachmann 1976; Desortová 1981; Felip and Catalan 2000; Wetzel 2001; Brumett 2006).

However, the nutrients shown in Figure 3.20 have been regularly measured in Deer Creek Reservoir by the Brigham Young University Reservoir. The concentrations of these nutrients fall within their respective, acceptable ranges for water bodies similar to that of Deer Creek. 
Therefore, they are not considered to be have a major influence on the correlations between chlorophyll-a and algae biovolume. The same can be said about temperature and turbidity in the reservoir.

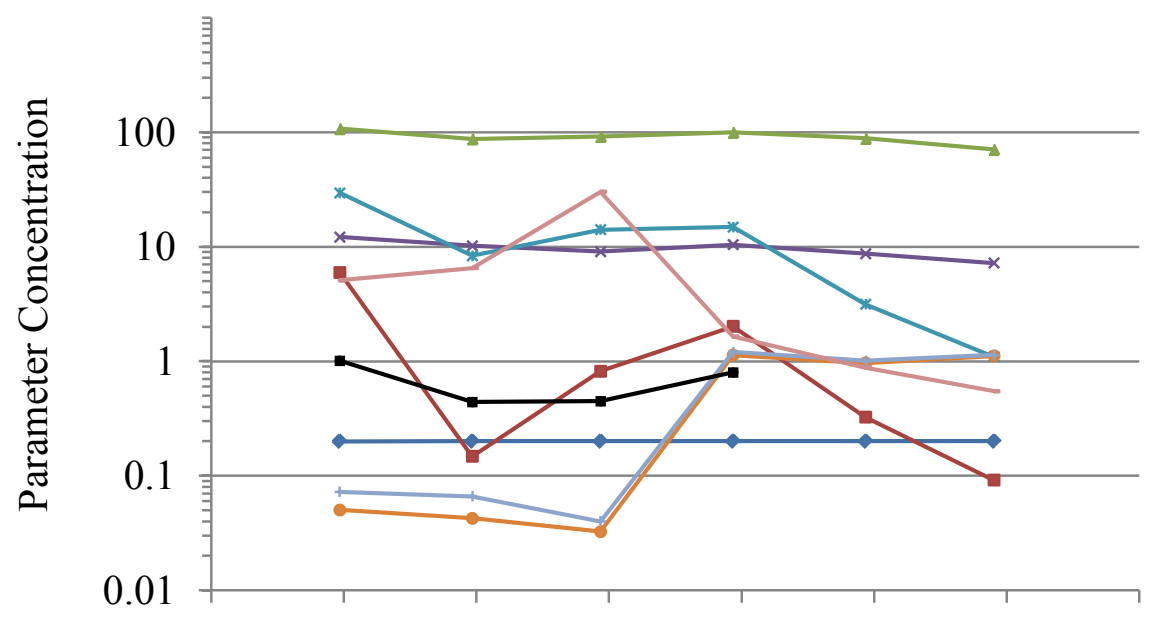

Apr-10 May-10 Jun-10 Jul-10 Aug-10 Sep-10 Oct-10 Nov-10

Month-Year

$\rightarrow-$ Mean(TDS g/L)
$\longrightarrow-$ Mean(LDO \%)
$\longrightarrow-$ Mean(Chlorophyll ug/L)
$\longrightarrow$ Mean(NH4Tot $(\mathrm{mg} / \mathrm{l}-\mathrm{N}))$
$\rightarrow-$ Mean(Phosphate(mg/L))

$\rightarrow$ Mean(Turbidity NTU)

$\rightarrow$ Mean $($ LDO $\mathrm{mg} / \mathrm{L})$

$\rightarrow-\operatorname{Mean}(\mathrm{NH} 4+(\mathrm{mg} / \mathrm{l}-\mathrm{N}))$

- Mean(NO3- $(\mathrm{mg} / \mathrm{l}-\mathrm{N}))$

Figure 3.20: Monthly averages of several water quality parameters on Deer Creek Reservoir in 2010 


\section{DISCUSSION AND CONCLUSIONS}

I found that the correlations between field-measured chlorophyll-a and algae biovolume are weak. The $\mathrm{R}^{2}$ values ranged from 0.00 to 0.75 between the four sites and within the euphotic zone. The poor results could be related to several different factors including algae species, nutrient loadings to the reservoir, chlorophyll-a concentration per algae cell volume, reservoir turnover, sampling methods, and other environmental factors such as temperature, turbidity, location of the reservoir, and light intensity which were not considered in depth as part of my research.

I observed variations in the regression strength and data trends between different species. In each zone, the dominant algal species showed the strongest correlation to field-measured chlorophyll-a. When the percentage biovolume of a species increased within a zone, the strength of its relationship to field chlorophyll-a measurement did so as well. Diatoms were the dominant species in most of the zones, and therefore correlated better with field-measured chlorophyll-a.

The strongest correlations observed were for those species which represented $75 \%$ or more of the total phytoplankton in each zone. However, when the percent biovolume of the dominant species dropped to below $50 \%$ and another species represented about $33 \%$ or higher, the strength of the relationship for each species became weaker and the data points were more 
random. Green algae showed a negative relationship with chlorophyll-a at all of the sites and in both areas of the euphotic zone.

I think that the current methods for sampling algae had a larger influence on the weak correlations than any of the potential issues discussed above. As described in section 2.2 of this paper, separate water samples were mixed and tested for algae content for both the upper and lower euphotic zones. The Central Utah Water Conservancy District assumes that by mixing the samples, an average algae biovolume is obtained and represents each zone. I disagree with this assumption. Figure 2.4, an example vertical profile measurement, shows that there can be significant variation in these zones, and that samples at the top and the bottom of the zone are probably not representative of the average. The combined sample is not representative of the entire zone. It only represents combined algae from the top and bottom of the upper and lower euphotic zones.

As was noted, after my analysis was complete, I learned that the algae samples taken to represent the lower euphotic zone were combined samples at 2 and 3 times the sample depth. I initially defined the lower euphotic zone to be a composite sample from the secchi depth and 3 times the secchi depth. Since the correlations for the upper euphotic zone were weak with the zone correctly defined by its water samples, I assume that a new analysis representing the lower euphotic zone correctly will not significantly affect my results.

With this in mind, I suggest four recommendations to evaluate and modify algae sampling protocol for the Central Utah Water Conservancy District: 
- Take and analyze duplicate algae samples

- Don't mix water samples

- Take chlorophyll-a readings at the same depths as the algae samples

- Take at least one more algae sample in the middle of both the upper and lower euphotic zones

Taking and analyzing duplicate algae samples will allow the district to determine any errors in their sampling methods or equipment. This will help them correct any of their sampling protocol as they see fit. More importantly, this would serve to quantify the variability of the algae concentration in the reservoir. As shown by the probe measurements, Figure 2.4, algae concentrations can vary significantly over very short vertical distances. I would expect that samples taken just a few minutes apart may have different values. Being able to quantify this variability would be important to help determine the validity of probe correlations.

Mixing the water samples is not representative of the whole zone (upper and lower euphotic zone) and could be the main factor behind the weak correlations because of the difficulty of matching a single probe measurement to a single laboratory measurement. I suggest to stop mixing the water samples and have them tested for algae separately at the lab. In relation to this, I also suggest that chlorophyll-a measurements be taken with the probe at the same depths as the algae samples are taken. As chlorophyll-a measurements are already being taken manually, this can be easily accomplished in the field. Doing so will most likely result in better correlations between chlorophyll-a and algae.

My last recommendation is to take an additional algae sample in the middle of the both the upper and lower euphotic zones. Our field vertical profile data show that chlorophyll-a concentration peaks within the euphotic zone and most frequently in the upper euphotic zone. 
This is shown in Figure 4.1 below, which shows the correct sampling depths. The profile shows that the chlorophyll-a concentration peaks at the bottom of the euphotic zone and it increases through both the upper and lower zones. The sample depths are represented by the boxes in the figure. If at least one more sample is taken in each part of the euphotic zone, the increase in chlorophyll-a concentration would most likely be captured. Any peak occurring in either zone would also most likely be captured. A higher resolution of sample points would better represent the distribution of algae in the water column. The samples should not be mixed, but should be paired separately with chlorophyll-a measurement taken at the same depths.

All of my recommendations will require more money spent in analyzing the water samples. I understand that by increasing the number of samples taken the sampling process becomes more expensive. However, investing in evaluating current sampling protocol and taking more samples could have long term benefits. By following my recommendations, I think that strong correlations between chlorophyll-a and algae will be found. As a result, the field probe can be used to estimate algae biovolume in Deer Creek Reservoir and fewer algae samples, if any, will be required. This will save the Utah Water Conservancy District both time and money in monitoring the water quality in the reservoir, allowing more time to be spent on analyzing the data that they collect.

More research can be done in relation to this study to evaluate the affects of the environment and nutrient loadings on chlorophyll-a concentrations. For example, phosphate and chlorophyll-a can be compared using data collected by the BYU Deer Creek research team. The strength of the correlation will indicate how much phosphate and other nutrients affect chlorophyll-a readings and therefore algae biovolume 


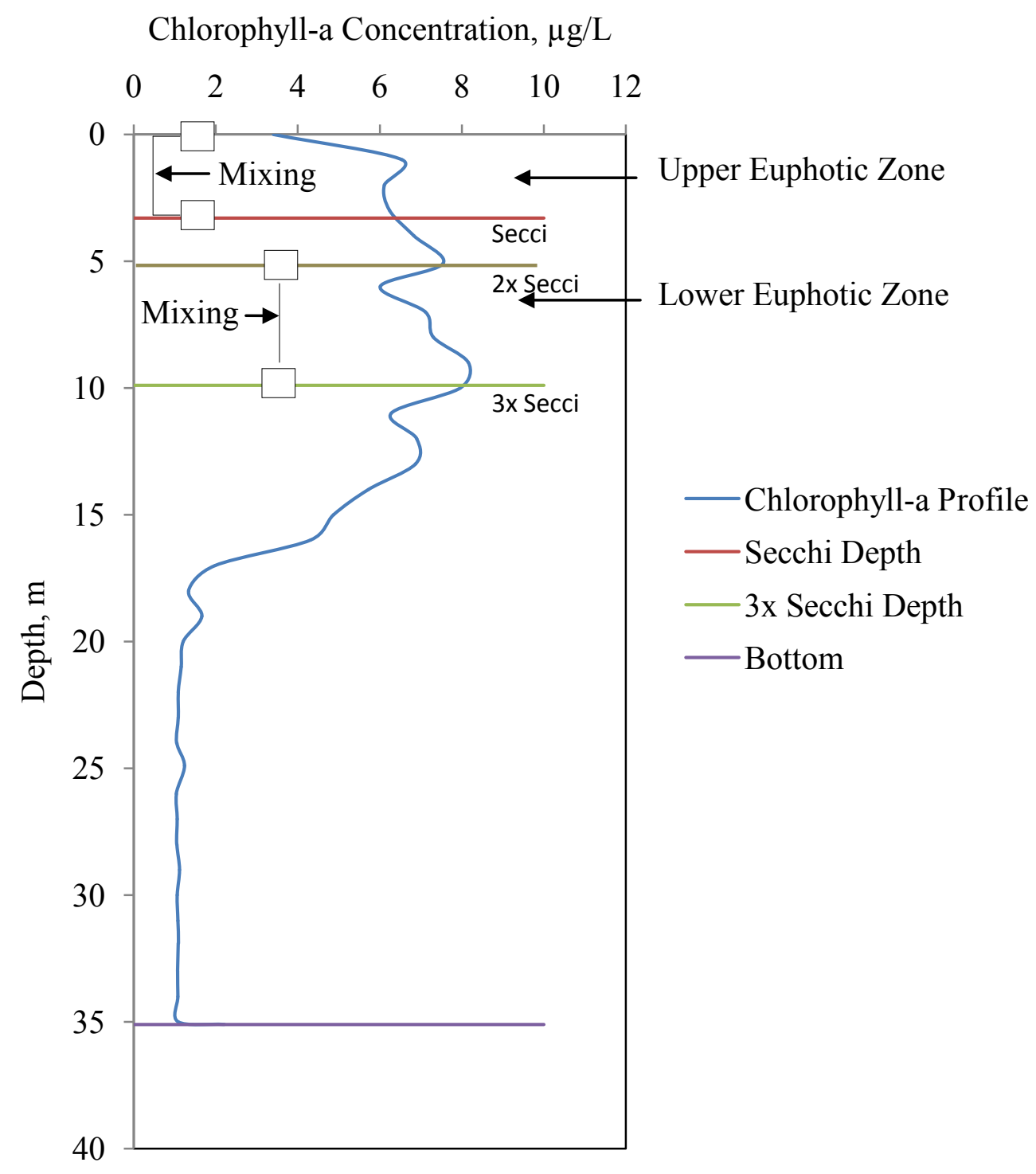

Figure 4.1: A chlorophyll-a profile at the Above Dam site showing the locations water samples were taken. The boxes represent the locations of the algae samples. Mixing of the samples is shown by the lines connecting the boxes both the upper and lower euphotic zone.

The suggestions made to the Central Utah Water Conservancy District to modify their sampling methods will allow for better results related to this study. These results will then allow them to evaluate the options, including cost and time, to limit their algae sampling and rely on estimates using the chlorophyll-a optical sensor. 


\section{REFERENCES}

Association, C. W. T. (2010). "Connecticut Water Trails Program." 2011, from http://connecticutwatertrails.com/CWTA\%20-\%20Lake\%20-\%20Lake\%20Ecology\%20\%20Zones\%20Of\%20A\%20Lake.htm.

Bell, T. M. (2009). Provo River Project.

Brumett, T. (2006). Chlorophyll Information Presentation, Turner Designs.

Canfield Jr, D., S. Linda, et al. (1985). "CHLOROPHYLL BIOMASS NUTRIENT RELATIONSHIPS FOR NATURAL ASSEMBLAGES OF FLORIDA PHYTOPLANKTON1." JAWRA Journal of the American Water Resources Association 21(3): 381-391.

David Eckhoff, P. D., P.E., Team Leader, P. E. Alane Boyd, Project Manager, et al. (2002). Deer Creek Reservoir TMDL, PSOMAS.

Desortová, B. (1981). "Relationship between Chlorophyll- $\alpha$ Concentration and Phytoplankton Biomass in Several Reservoirs in Czechoslovakia." Internationale Revue der gesamten Hydrobiologie und Hydrographie 66(2): 153-169.

Felip, M. and J. Catalan (2000). "The relationship between phytoplankton biovolume and chlorophyll in a deep oligotrophic lake: decoupling in their spatial and temporal maxima." Journal of Plankton Research 22(1): 91.

Gaufin, A. and D. McDonald (1965). "Factors influencing algal productivity in Deer Creek Reservoir, Utah." Transactions of the American Microscopical Society 84(2): 269-279.

Jones, J. and R. Bachmann (1976). "Prediction of phosphorus and chlorophyll levels in lakes." Journal (Water Pollution Control Federation) 48(9): 2176-2182. 
Kiefer, D. (1973). "Fluorescence properties of natural phytoplankton populations." Marine Biology 22(3): 263-269.

Nicholls, K. H. and P. J. Dillon (1978). "An Evaluation of Phosphorus-ChlorophyllPhytoplankton Relationships for Lakes." Internationale Revue der gesamten Hydrobiologie und Hydrographie 63(2): 141-154.

OECD (1982). Eutrophication of waters: Monitoring, assessment and control, OECD Paris.

Office of Wetlands, O., \& Watersheds (2010). National Lakes Assessment: A Collaborative Survey of the Nation's Lakes. U. S. E. P. Agency.

Rushforth, S. R. and S. J. Rushforth. (2005, March 15, 2006). "Protocols for the Analysis of Algal Samples." Retrieved January 10, 2011.

Vörös, L. and J. Padisák (1991). "Phytoplankton biomass and chlorophyll-a in some shallow lakes in central Europe." Hydrobiologia 215(2): 111-119.

Wetzel, R. G. (2001). Limnology: Lake and River Ecosystems, Academic Press. 